ARTICLE

\title{
Sea-ice derived meltwater stratification slows the biological carbon pump: results from continuous observations
}

Wilken-Jon von Appen (10 ${ }^{1 凶}$, Anya M. Waite ${ }^{1,2}$, Melanie Bergmann (1) ${ }^{1}$, Christina Bienhold ${ }^{1,3}$, Olaf Boebel ${ }^{1}$, Astrid Bracher (10) 1,4, Boris Cisewski (1) 5, Jonas Hagemann (10) 1, Mario Hoppema (D) 1, Morten H. Iversen (1) 1,6, Christian Konrad 1,6, Thomas Krumpen', Normen Lochthofen (1) 1, Katja Metfies (1) 1, Barbara Niehoff', Eva-Maria Nöthig (1) 1, Autun Purser (10 1, Ian Salter (10 1,7, Matthias Schaber ${ }^{5}$, Daniel Scholz (i) 1,

Thomas Soltwedel', Sinhue Torres-Valdes (1) 1, Claudia Wekerle1, Frank Wenzhöfer (1) 1,3, Matthias Wietz (i) ${ }^{1,3}$ \& Antje Boetius (iD) 1,3,6

The ocean moderates the world's climate through absorption of heat and carbon, but how much carbon the ocean will continue to absorb remains unknown. The North Atlantic Ocean west (Baffin Bay/Labrador Sea) and east (Fram Strait/Greenland Sea) of Greenland features the most intense absorption of anthropogenic carbon globally; the biological carbon pump (BCP) contributes substantially. As Arctic sea-ice melts, the BCP changes, impacting global climate and other critical ocean attributes (e.g. biodiversity). Full understanding requires year-round observations across a range of ice conditions. Here we present such observations: autonomously collected Eulerian continuous 24-month time-series in Fram Strait. We show that, compared to ice-unaffected conditions, sea-ice derived meltwater stratification slows the BCP by 4 months, a shift from an export to a retention system, with measurable impacts on benthic communities. This has implications for ecosystem dynamics in the future warmer Arctic where the seasonal ice zone is expected to expand.

\footnotetext{
${ }^{1}$ Alfred Wegener Institute, Helmholtz Centre for Polar and Marine Research, Bremerhaven, Germany. ${ }^{2}$ Department of Oceanography and the Ocean Frontier Institute, Dalhousie University, Halifax, NS, Canada. ${ }^{3}$ Max Planck Institute for Marine Microbiology, Bremen, Germany. ${ }^{4}$ Institute of Environmental Physics, University of Bremen, Bremen, Germany. ${ }^{5}$ Thünen Institute of Sea Fisheries, Bremerhaven, Germany. ${ }^{6}$ MARUM, University of Bremen, Bremen, Germany.

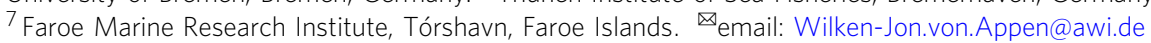


$\mathrm{P}$ hytoplankton require light to flourish. Stratification keeps algal cells in surface layers. In the Arctic Ocean, this is often controlled by sea ice melt and brine release. The extent of stratification, often simplified as mixed layer depth (MLD), impacts the timing of biological production in nutrient-rich open waters ${ }^{1}$, at the ice edge on Arctic shelves ${ }^{2}$, and under the ice ${ }^{3}$. For example, in a MLD of $20 \mathrm{~m}$, a bloom can start 4-6 weeks earlier than in a MLD of $100 \mathrm{~m}^{4}$. Large interannual differences in the timing of blooms may be challenging for higher trophic levels due to temporal and spatial mismatches with key prey, and could therefore impact trophic interactions considerably ${ }^{5}$. Also, different pelagic bloom scenarios can result in different proportions of sinking algal aggregates, fecal pellets, and marine snow, and the sea-ice cover plays an important role in such scenarios in the $\mathrm{Arctic}^{6,7}$. Consequently, the structure, sinking rate, biogeochemical composition, and nutritional quality of particles reaching the benthic community may change with Arctic warming and sea-ice retreat $^{8}$.

Stratification affects both light availability and nutrient supply as essential factors for phytoplankton growth. Typically, the open ocean regions of the Arctic are characterized by a wellstratified surface layer with rather low nutrient concentrations, and limited replenishment, leading to fast depletion upon the onset of the productive season ${ }^{9}$. Subsurface waters, however, are richer in nutrients ${ }^{9,10}$ and upwelling of these nutrients at the ice edge may support patchy phytoplankton blooms, which can account for half of the regional production within a season ${ }^{11}$. When the ice recedes during spring/summer, ice-edge blooms may form in the warm water in the Nordic and Barents Seas ${ }^{12}$ and move with the receding ice. In the Greenland Sea, three successive phases of phytoplankton growth were identified: first under ice, then at the ice edge, and finally in the open water with a subsurface chlorophyll a maximum ${ }^{3}$. North of the Greenland Sea in Fram Strait, primary production can change by $0.3 \mathrm{~g} \mathrm{C} \mathrm{m}^{-2}$ day $^{-1}$ between years, with higher values occurring in years when more sea ice is exported southwards from the Arctic Ocean ${ }^{13,14}$.

The understanding of the ocean's role in the global carbon balance and in response to climate change is an urgent scientific task ${ }^{15}$. The North Atlantic-Arctic gateways are sites of intense climate-induced changes affecting food-webs and carbon export ${ }^{16,17}$. Thus, moving from the concept of a single spring bloom to a nuanced and mechanistic understanding of Arctic productivity including the role of sea ice is essential for our understanding of the biological carbon pump (BCP) at high latitudes.

The FRAM (Frontiers in Arctic Marine Monitoring) Ocean Observing System in Fram Strait ${ }^{18}$ provides continuous in-situ data that can help bridge key gaps in ecosystem research with regard to temporal dynamics. Two mooring clusters, equipped throughout the water column with a comprehensive suite of physical and biogeochemical sensors as well as autonomous sampling systems, are located in central (mooring cluster "HGIV") and eastern (mooring cluster "F4") Fram Strait (Fig. 1), the only deep-water gateway connecting the Arctic Ocean to the rest of the world's oceans. Relatively warm and salty Atlantic Water (AW) flows northward with the West Spitsbergen Current (WSC, Fig. 1, mooring location F4) ${ }^{19}$ in eastern Fram Strait. Some of this AW flows westward in an energetic eddying recirculation (mooring location HG-IV) ${ }^{20}$ and subducts below the colder and fresher Polar Water (PW) exiting the Central Arctic Ocean. This subduction stirs and mixes AW and PW on small horizontal scales $^{21}$. The southward flowing PW carries sea ice from the Transpolar Drift and forms the East Greenland Current (EGC, Fig. 1). The confluence of the AW (which can melt sea ice) and the southward flowing sea ice results in a semi-stationary ice edge

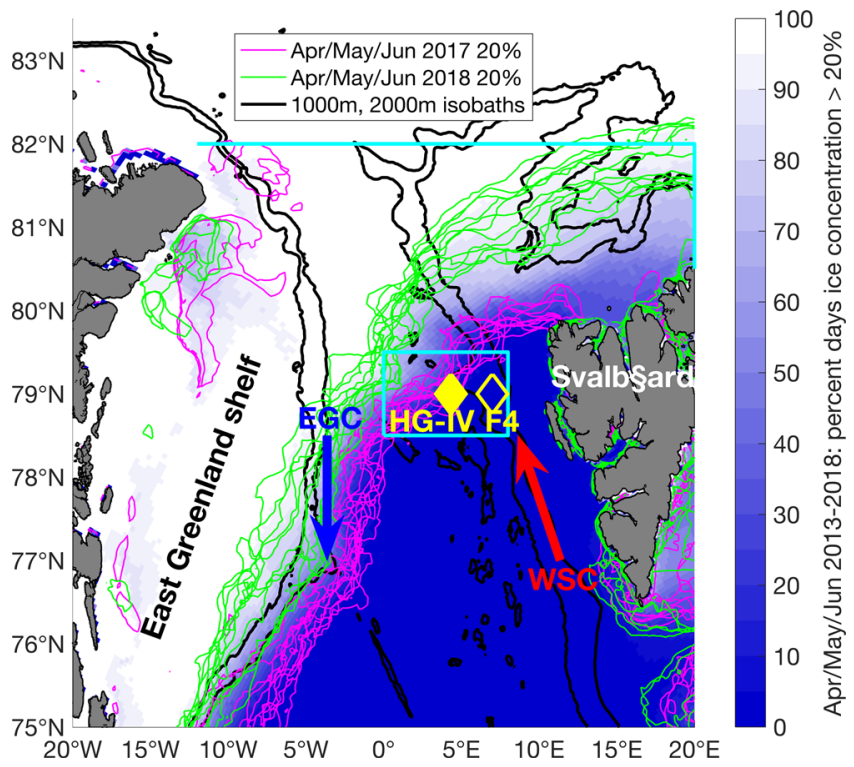

Fig. 1 Map of mooring locations, major currents, and ice coverage in Fram Strait. The percentage of days in April/May/June 2013-2018 during which sea ice cover exceeded $20 \%$ is shown in white-blue. The width of the marginal ice zone ( $20 \%$ contour to $80 \%$ contour) was typically less than $50 \mathrm{~km}$. The weekly $20 \%$ sea ice concentration contours for the study period in April/May/June are shown in magenta (2017) and green (2018). The meltwater regime typically applies in the area covered by the variability of the $20 \%$ contours. The mixed layer regime by contrast applies well east/ south $(\sim 50-100 \mathrm{~km})$ of the $20 \%$ contours. Thus mooring HG-IV is in the meltwater regime in 2017 and in the mixed layer regime in 2018. The major currents in the area are indicated schematically: West Spitsbergen Current (WSC) and East Greenland Current (EGC). The location of the moorings discussed in this study are marked in yellow: F4 in the WSC (data shown in Figs. S1-S3) and HG-IV west of the WSC (data shown below). The 1000-m and 2000-m isobaths are shown in black and land in gray. The gate and box used in Figs. 2 and 9, respectively, are shown in cyan.

(here defined as $20 \%$ sea ice concentration, but not sensitive to the exact definition). Compared to other regions of the Polar oceans, the seasonal migration of the ice edge of $50-100 \mathrm{~km}$ in Fram Strait is small ${ }^{22}$, meaning the seasonal ice zone is narrow. It covers an area of approximately $40,000 \mathrm{~km}^{2}$ and, due to its high productivity, forms an ecologically important feeding ground for marine birds and mammals ${ }^{23}$.

Here we investigate the effect of varying sea ice export from the Arctic Ocean on local biogeochemical processes and the biological carbon pump. We hypothesize that high ice-export results in strong meltwater stratification leading to the formation of a thin productive layer near the surface. By contrast, low sea ice export results in a classical (deeper) mixed layer which features a bloom of pelagic diatoms that is rapidly exported to the seafloor. Building on work that was partially able to achieve this, we tested the hypothesis that sea ice export is a key regulating factor not only for the biological carbon pump but also for the plankton community composition and retention efficiency.

\section{Results}

Ice export and related stratification regimes. Key to understanding processes at our mooring sites is their location in a given year relative to the ice extent in the marginal ice zone of Fram Strait (Fig. 1). Ice extent is driven by southward sea ice exportthe Transpolar Drift-from the Arctic Ocean proper across Fram Strait, as well as by local winds and currents. This sea ice export 

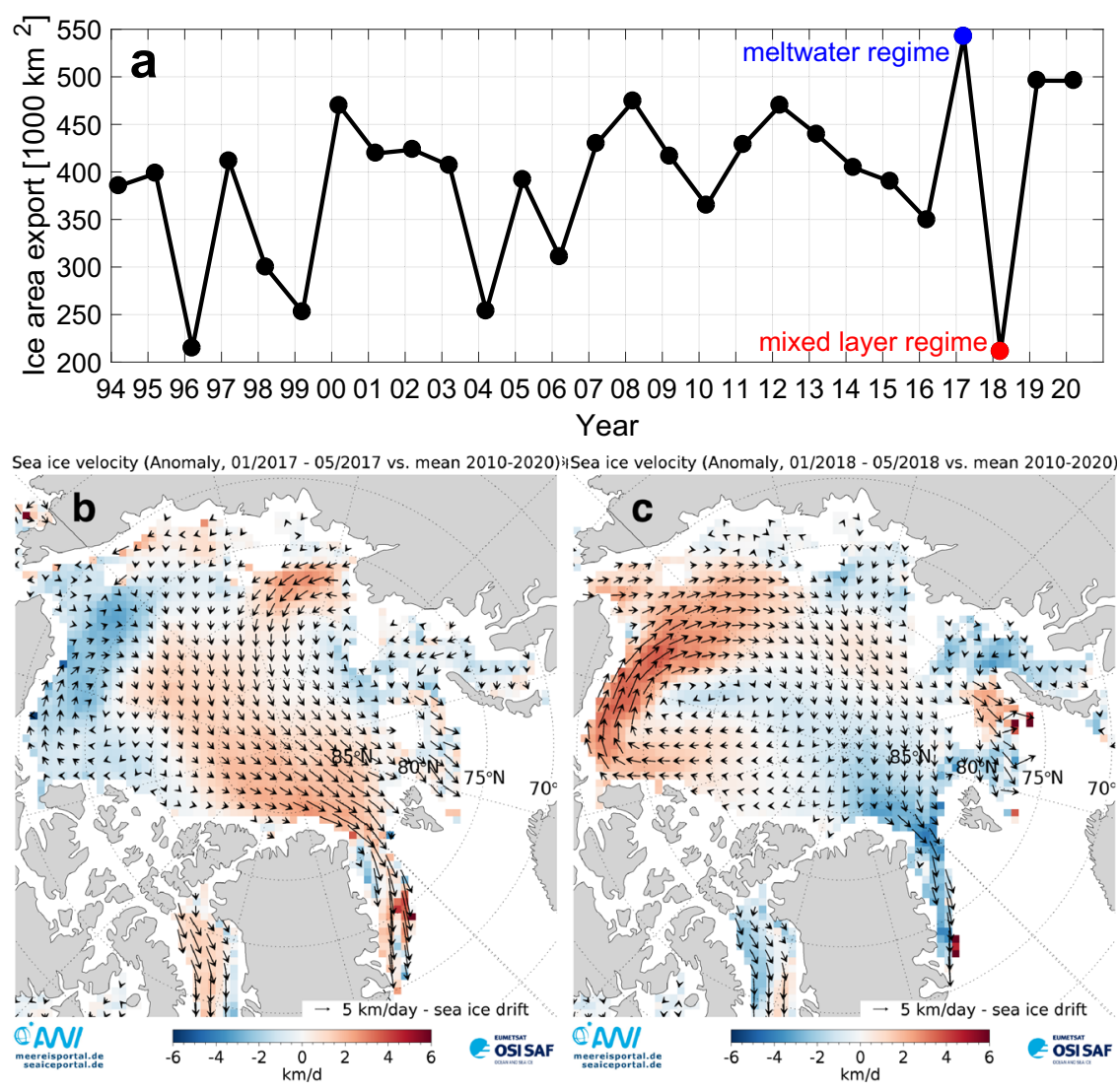

Fig. 2 Fram Strait winter ice export and Arctic winter sea ice velocity anomalies. a Southward sea ice area export $\left[1000 \mathrm{~km}^{2}\right]$ in winter (January to May) between 1994 and 2020 across a zonal gate at $82^{\circ} \mathrm{N}$ between $12^{\circ} \mathrm{W}$ and $20^{\circ} \mathrm{E}$ and a meridional gate at $20^{\circ} \mathrm{E}$ between $80.5^{\circ} \mathrm{N}$ and $82^{\circ} \mathrm{N}($ see cyan gate in Fig. 1) as used in ref. ${ }^{105}$. The winter values preceding the two discussed stratification regimes are marked. $\mathbf{b}$, $\mathbf{c}$ Sea ice velocity [km day $\left.{ }^{-1}\right]$ vectors and anomaly from 2010-2020 mean in color. b is January to May 2017 average and $\mathbf{c}$ is January to May 2018 average. Note that the sea ice velocity north of Fram Strait was anomalously large in 2017 and anomalously small in 2018.

in turn is driven by the atmospheric surface pressure gradient between Greenland and Svalbard ${ }^{24}$. As a result, there are substantial interannual differences in ice export through Fram Strait. Overall, Arctic warming has increased Transpolar Drift velocity ${ }^{25}$, which in turn has led to an intensified sea ice area export out of Fram Strait in winter (January-May, Fig. 2a). However, an exact quantification of trends in export rates remains difficult, as satellite-based motion estimates show high uncertainties at export gateways ${ }^{26}$. The ice area export in 2017 was anomalously large while it was anomalously small in 2018 (Fig. 2b, c). Consequently, in spring/summer 2018, the ice edge was $>50 \mathrm{~km}$ to the northeast of mooring HG-IV in the central Fram Strait while the ice edge was above the mooring in spring/ summer 2017 (Fig. 1, see below).

The presence of ice in 2017 provided a source of meltwater that resulted in a very strong $\left(N^{2}=1 \times 10^{-4} \mathrm{~s}^{-2}\right)$, but temporally variable haline (salinity driven) stratification at mooring HG-IV as estimated from our time series observations between $30 \mathrm{~m}$ (the shallowest depth that was deemed safe for moored observations) and $55 \mathrm{~m}$ (Figs. 3a, c and 4e). However, shipboard observations showed that stratification between $0 \mathrm{~m}$ and $30 \mathrm{~m}$ in fact was 10 fold stronger than in the layer between $30 \mathrm{~m}$ and $55 \mathrm{~m}$ (Fig. 3a, c). Surface salinities as low as 30.5 were observed in the top $3 \mathrm{~m}$ in July 2017 when meltwater contributed up to $1 / 6$ by volume assuming that the surface water originated only from sea ice melted in Atlantic Water. Furthermore, there was no mixed layer (or if it was there, it must have been $<5 \mathrm{~m}$ thick), similar to what has been reported as summer conditions across the central Arctic Ocean ${ }^{27}$.
By contrast, there was a much weaker stratification across a mixed layer of approximately $50 \mathrm{~m}$ at the same location and time period in spring/summer 2018 (Figs. 3b, d and 4c). Most of that stratification was also due to the vertical salinity gradient (Fig. 4e). Winter-time deep mixing occurred in both years and restored nutrient concentrations in the surface (Fig. 5e), but in 2017 it was intermittently interrupted by meltwater advection as early as March into the region. This ceased on $\sim 15$-May-2017 as the surface heat flux turned positive (Fig. 4b), i.e., the atmosphere started to warm the ocean. In the following year, deep mixing persisted from 15-Dec-2017 until 01-May-2018 when the surface heat flux turned positive (Fig. 4b), and a period of relatively weaker, but uninterrupted stratification started. 2018 had the highest May air temperatures in Svalbard since $1898^{28}$.

Our time series thus covered two distinct stratification regimes during the spring blooms in the two-year observation period (summer 2016 to summer 2018): Strong salinity stratification due to meltwater (spring/summer 2017, "MW regime") and relatively weak stratification with a significant mixed layer (spring/summer 2018, "ML regime").

The mooring measurements in our high-resolution time series must be understood within this changing oceanographic context, particularly in the vertical dimension. As we demonstrate below (and summarize in Table 1), the strong meltwater-induced stratification in 2017 resulted in primary production at depths above the moored sensors and samplers located at $30 \mathrm{~m}$ depth. By contrast, in 2018, primary production took place in a weakly stratified mixed layer and the upper measurement depth $(30 \mathrm{~m})$ was within this productive mixed layer. 

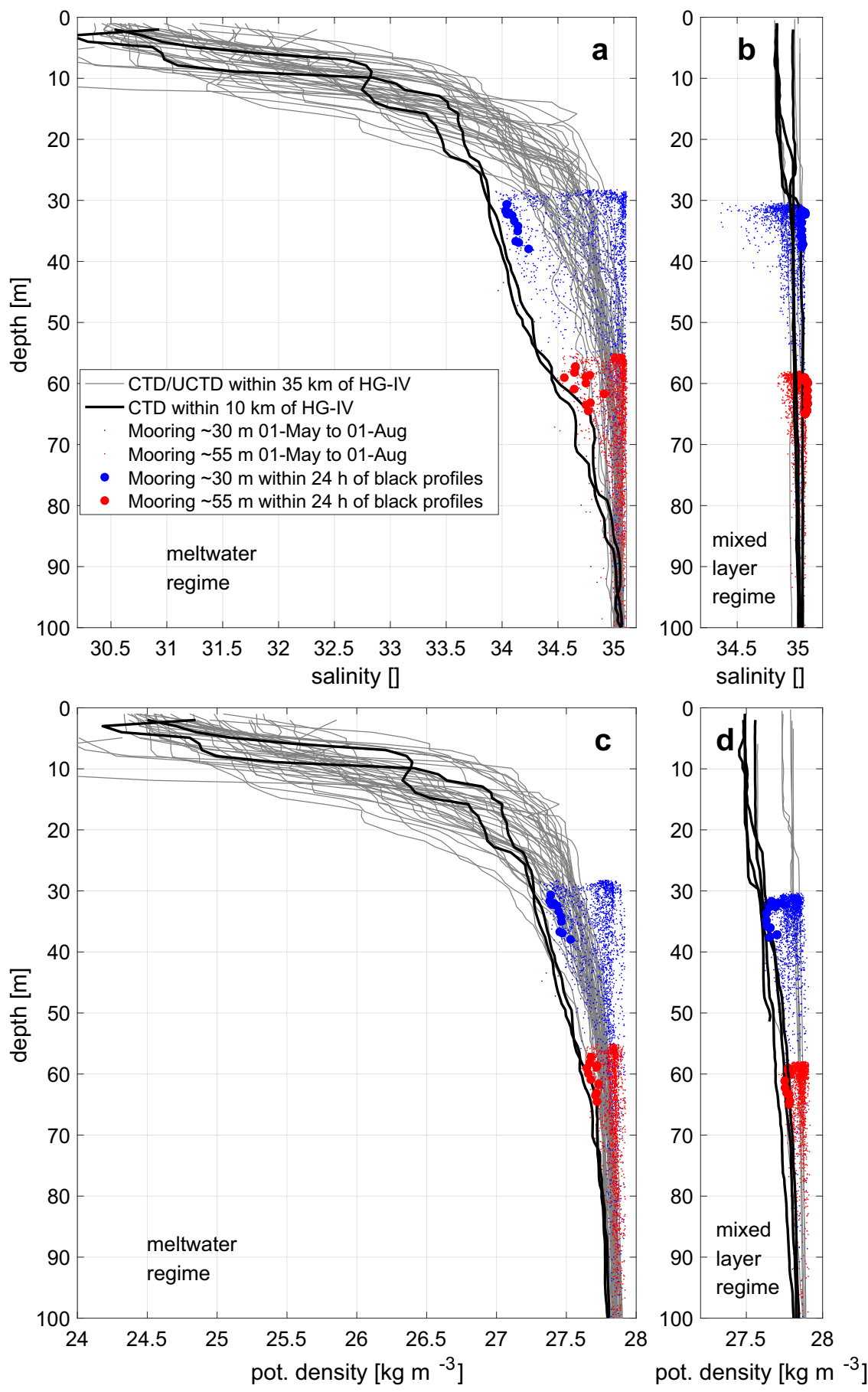

Fig. 3 Upper ocean stratification from comparison of shipboard and mooring data. $\mathbf{a}, \mathbf{b}$ Salinity [] and $\mathbf{c}, \mathbf{d}$ potential density $\left[\mathrm{kg} \mathrm{m}^{-3}\right]$ in 2017 (meltwater regime in a, c) and 2018 (mixed layer regime in b, d). All CTD/UCTD casts within $35 \mathrm{~km}$ of HG-IV mooring location (gray lines). All CTD casts within $10 \mathrm{~km}$ of HG-IV (black lines). All mooring measurements between 01-May and 01-Aug at $30 / \sim 55 \mathrm{~m}$ (blue/red dots). Mooring measurements within $24 \mathrm{~h}$ of black profiles (large blue/red dots). Note that the aspect ratio of the subplots of the respective parameters is identical.

Biogeochemical and biological characteristics of the blooms and the associated carbon export. We use the detailed biogeochemical time series provided by our mooring data (Tables S1-S3) to approximately quantify total primary productivity and estimate seasonal new production (nitrate driven primary production) for the two phytoplankton blooms associated with the contrasting sea ice and stratification regimes detailed above.

Mixed layer regime (spring/summer 2018). The ML regime that we observed during spring/summer 2018 is typical for conditions when the upper ocean is mostly unaffected by sea ice (the ice edge was $>50 \mathrm{~km}$ from our observation location during this period, Fig. 4a). The high winter nutrient values (Fig. 5e) indicate that they have been resupplied by deep mixing down to more than $250 \mathrm{~m}$, unlike the situation in western Fram Strait where the constant halocline is associated with a deep and permanent nitracline ${ }^{29}$. From the end of the Polar night in mid February until the end of April, the average light level experienced by a phytoplankton cell in the $>250 \mathrm{~m}$ deep mixed layer (Fig. $4 \mathrm{c}$ ) was too low to support growth $\left(<10 \mu \mathrm{mol} \mathrm{m}{ }^{-2} \mathrm{~s}^{-1}\right.$, Fig. 5a red). As 

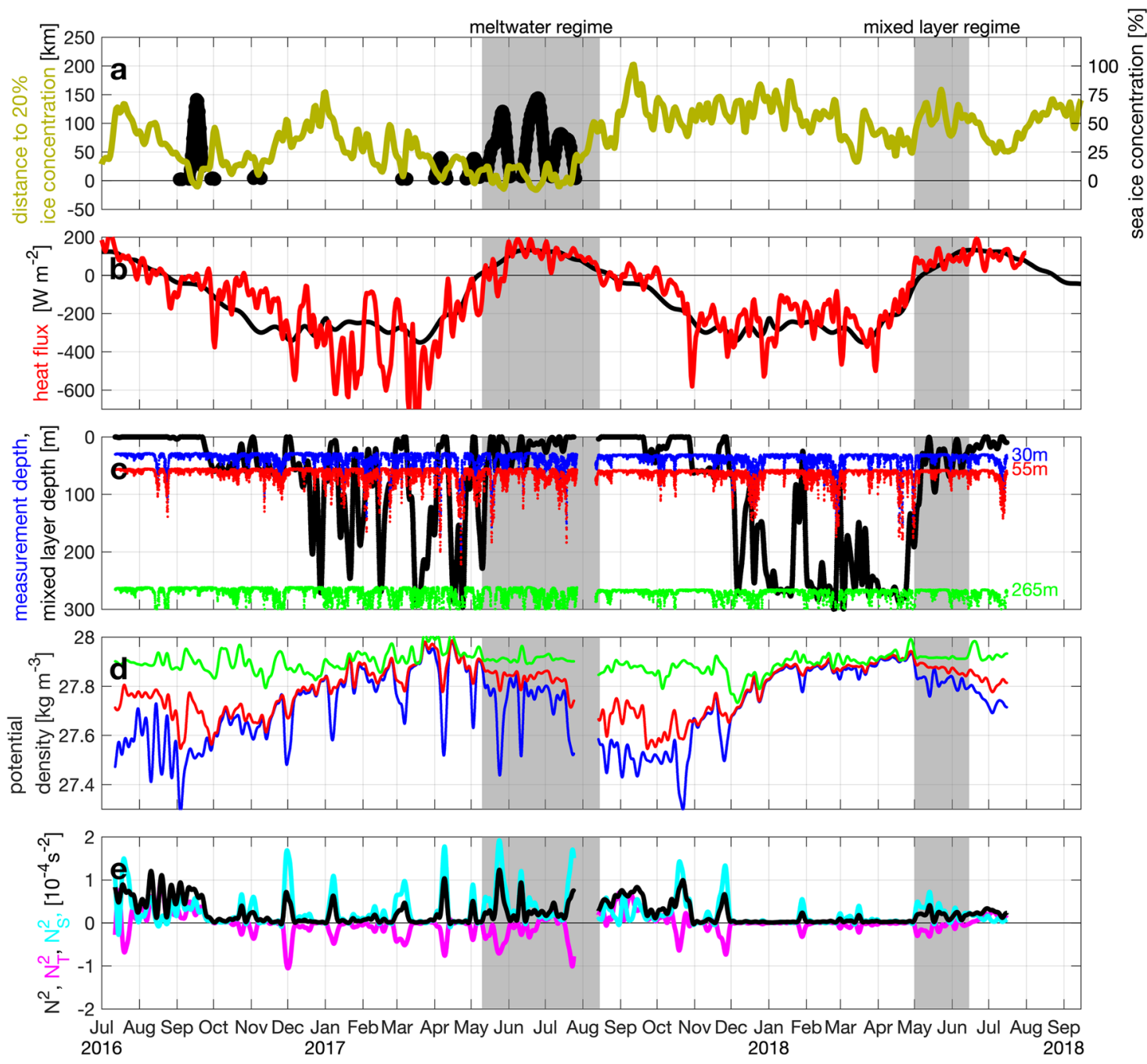

Fig. 4 Ice, heat flux, and upper ocean stratification at HG-IV. a Distance of mooring to 20\% sea ice concentration [km] (dark yellow), negative when sea ice concentration at mooring exceeded 20\%; sea ice concentration [\%] (plotted black when $>0 \%$ ) at AMSR-2 satellite grid point ( 5 km diameter) closest to mooring location; note the different $y$-scale for the sea ice concentration. b Net surface heat flux $\left[\mathrm{W} \mathrm{m}^{-2}\right]$ (red) at ERI-I reanalysis grid point $(\sim 30 \mathrm{~km}$ diameter) closest to mooring location and its smoothed climatology (black); positive values warm the ocean. c Measurement depths of sensors [m] at approximately $30 \mathrm{~m}$ (blue), $55 \mathrm{~m}$ (red), and $265 \mathrm{~m}$ (green); minimum estimate of the mixed layer depth [m] (black), actual mixed layer depth was likely somewhat deeper. d Potential density $\left[\mathrm{kg} \mathrm{m}^{-3}\right]$ at the three measurement depths as colored in Fig. 4c. e Stratification (buoyancy frequency $N^{2}$ [s ${ }^{-2}$ ], black) estimated from difference of $30 \mathrm{~m}$ and $55 \mathrm{~m}$ observations and temperature ( $\mathrm{N}^{2}$, magenta) and salinity $\left(\mathrm{N}^{2} \mathrm{~s}\right.$, cyan) contributions to stratification; note that stratification above $30 \mathrm{~m}$ in 2017 was likely 10-times larger than values given here (Fig. 3). The bloom periods of the meltwater (10-May to 15Aug-2017) and mixed layer (01-May to 15-Jun-2018) regimes are marked by gray backgrounds. All sensor data shown in Figs. 4-6 are hourly data that have been lowpass filtered with a 5-days cutoff.

the moderate stratification started around 01-May-2018, the photosynthetically available radiation (PAR) in the mixed layer increased by about an order of magnitude (Fig. 5a). This induced a bloom of pelagic diatoms-evident from both sequence abundances (Fig. 6a) and microscopic cell counts ${ }^{30}$ and an associated decrease of nitrate and $\mathrm{pCO}_{2}$, an increase in chlorophyll and $\mathrm{pH}$ (Fig. 5b-e), and an increase in photosynthesis-derived oxygen, leading to a decrease in apparent oxygen utilization (AOU). The early bloom approximately followed Redfield stoichiometry with $\sim 7 \mu \mathrm{mol} \mathrm{l}^{-1}$ of oxygen produced, $\sim 6 \mathrm{~mol}^{-1}$ of carbon taken up, and $\sim 0.6 \mu \mathrm{g} \mathrm{l}^{-1}$ of chlorophyll $a$ produced per $\mu \mathrm{moll}^{-1}$ nitrate taken up (Fig. 7). Note that oxygen will leave the mixed layer to the atmosphere while carbon dioxide will enter the mixed layer and therefore our estimates of $7 \mu \mathrm{mol} \mathrm{I}^{-1}$ of oxygen produced and $6 \mu \mathrm{mol} 1^{-1}$ of carbon taken up per $\mu \mathrm{moll} \mathrm{l}^{-1}$ nitrate represent lower bounds.
Chlorophyll $a$ (Fig. 5b) in the mixed layer increased with e-folding growth rates of $\sim 0.2$ day $^{-1}$ (Fig. S4d) eventually reaching concentrations of $7 \mu \mathrm{gl}^{-1}$. These values appear consistent compared to most previous observations in the region (mean of $4.8 \mu \mathrm{g} \mathrm{l}^{-1}$ for 1991-2015 with a maximum of $7.2 \mu \mathrm{gl}^{-1}$ measured in May 1997) ${ }^{31}$. The chlorophyll increase coincided with shading by the increased turbidity from growing phytoplankton reducing PAR levels at $30 \mathrm{~m}$ to values equivalent to those at the end of the preceding Polar night (Fig. 5a) consistent with the expected euphotic depth at those chlorophyll concentrations of $\sim 15 \mathrm{~m}^{32,33}$. The diatom bloom coincided with elevated relative abundances of Bacteroidetes (Fig. $6 \mathrm{~b}$ ) that likely utilized algal substrates, resembling bloom dynamics and metabolic interrelations in temperate regions ${ }^{34}$. The slightly lower oxygen production at $55 \mathrm{~m}$ (compared to $30 \mathrm{~m}$ ) suggests this depth is at or below the base of the productive mixed layer. We therefore 

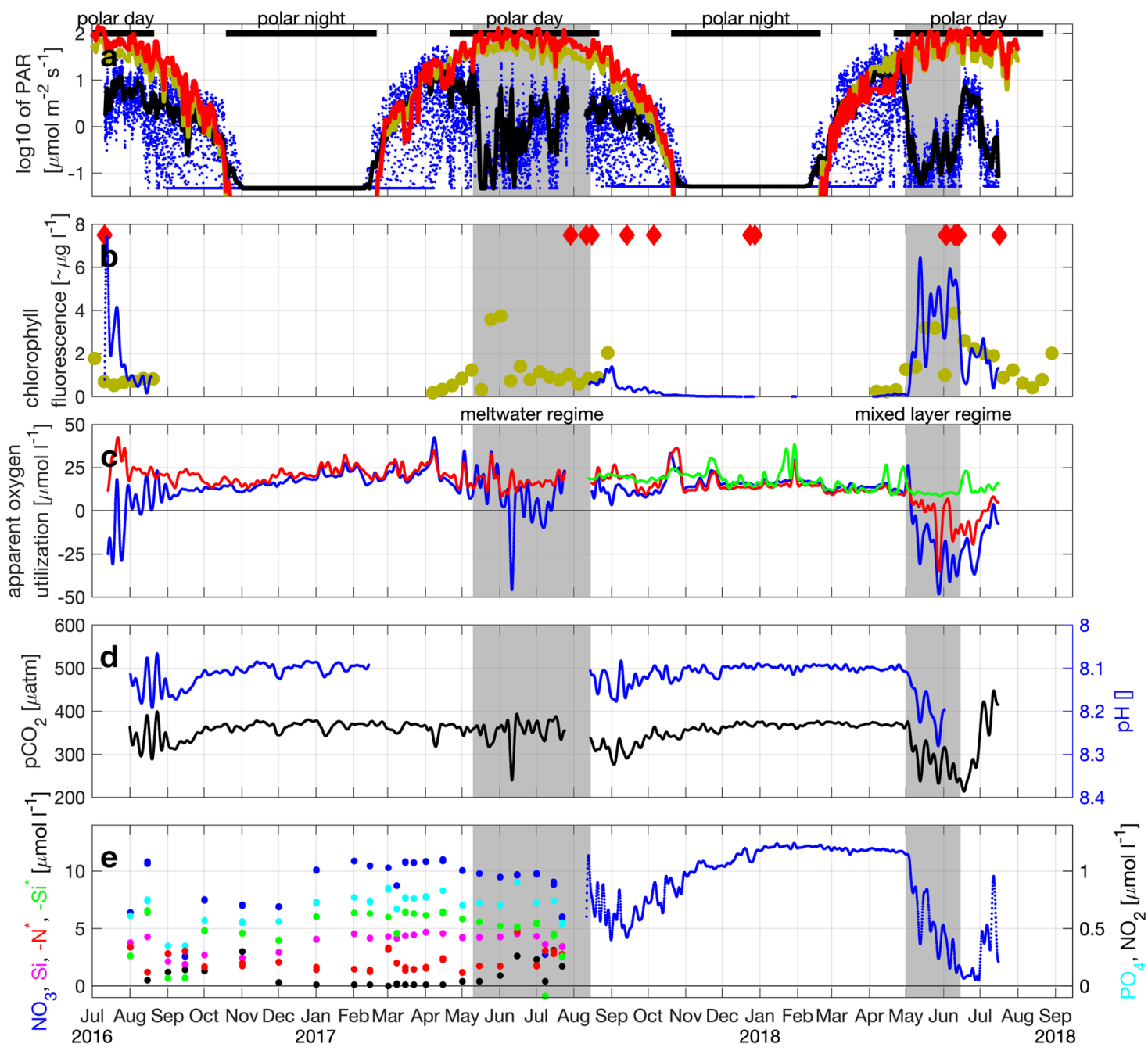

Fig. 5 Upper ocean biogeochemistry at HG-IV from upper instrument depth $\mathbf{( - 3 0} \mathbf{~ m})$. a Logarithm of photosynthetically available radiation $\left[\mu \mathrm{mol} \mathrm{m}^{-2} \mathrm{~s}^{-1}\right.$ ] from hourly sensor measurements at depth (blue) and their 5-day average (black); from reanalysis at the surface reduced to $30 \mathrm{~m}$ depth using a constant extinction coefficient in order to make it comparable to the sensor measurements (dark yellow); and from the reanalysis value distributed over the mixed layer depth (red). $\mathbf{b}$ Chlorophyll a concentration $\left[\sim \mu \mathrm{g} \mathrm{I}^{-1}\right]$ from chlorophyll fluorescence sensor measurements (blue); and from average of Sentinel $3 \mathrm{~A}$ OLCl satellite grid points within 30-km radius of mooring location (dark yellow); times when individual 1-second measurements of scattering exceeded $0.002 \mathrm{~m}^{-1} \mathrm{sr}^{-1}$ (red diamonds) indicative of aggregation. c Apparent oxygen utilization $\left[\mu \mathrm{mol} \mathrm{I}^{-1}\right.$ ] at the three measurement depths as colored in Fig. $4 \mathrm{c}$. d pCO 2 [ $\mu$ atm] (black) and $\mathrm{pH}$ [] (blue); note the reversed $y$-axis for $\mathrm{pH}$. e Inorganic nutrients [ $\mu \mathrm{mol} \mathrm{I}^{-1}$ ] from water samples in 2016-2017 and from nitrate sensor in 2017-2018; nitrate (blue), silicate (magenta), phosphate (cyan), nitrite (black); negative of $\left(\mathrm{N}^{\star}=\right.$ nitrate-phosphate $\left.{ }^{\star} 16\right)$ (red); negative of $\left(\mathrm{Si}^{\star}=\mathrm{silicate}\right.$-nitrate) (green); note the different $y$-scale for phosphate and nitrite.

estimate that the ML is on the order of $50 \mathrm{~m}$. Integrating nitrate $\left(\sim 12 \mu \mathrm{mol} \mathrm{l}^{-1}\right)$ over this depth indicates the standing stock available at the onset of the productive season is $0.6 \mathrm{~mol} \mathrm{~m}^{-2}$ of nitrate (Table 1). This is before considering likely resupply by mixing across the base of the mixed layer, and would-assuming the Redfield ratio-potentially support a total production of $\sim 50 \mathrm{~g} \mathrm{~m}^{-2}$ of carbon (Table 1). Three different estimates of bloom production from three synchronous data sets $\left(\mathrm{pCO}_{2}\right.$, nitrate, and maximum chlorophyll concentration combined with a chlorophyll to carbon ratio of 50; Table 1) result in estimates of $\sim 72,50$, and $13 \mathrm{~g} \mathrm{~m}^{-2}$ of carbon (Table 1). Note that the estimate based on chlorophyll converted to carbon is a lower bound. It neglects that some organic matter export will happen before the maximum in observed chlorophyll is reached and that further growth will occur after the maximum has been reached. We attribute this small range between the different estimates to the conversion factors used and assumptions inherent in the different methods, and consider it a strength of the high-resolution time series, where the temporal variability is fully constrained and key events are not missed.

The bloom in the ML regime (2018) was dominated by pelagic diatoms (Chaetoceros and Thalassiosira) (Fig. 6a). Associated with the bloom onset, the zooplankton and fish biomass as estimated by acoustic backscatter quickly increased within a few days (Fig. 6c). It appears plausible that the suspension feeding herbivorous zooplankton responded directly to the diatoms which are their preferred food source ${ }^{35,36}$ and that they produced fast-sinking fecal pellets exporting particulate organic carbon (POC) early in the season as measured in multiple depths (Fig. 6d). Chloroplasts can remain intact during consumption by zooplankton ${ }^{37}$ consistent with the green color of the sedimented material observed on the seafloor (Fig. 6e). In addition, the diatoms likely formed fast-sinking aggregates (aggregation marked in red in Fig. 5b).

Within 2-3 weeks after the bloom onset, particles had reached $200 \mathrm{~m}$ (Fig. 6d) and $1200 \mathrm{~m}$ depth (not shown). A major POC 
Table 1 Physical and biogeochemical observations over the bloom duration.

\begin{tabular}{|c|c|c|c|c|c|}
\hline Parameter & Unit & $\begin{array}{l}\text { Meltwater regime } \\
\text { (spring/ } \\
\text { summer 2017) }\end{array}$ & $\begin{array}{l}\text { Mixed layer regime } \\
\text { (spring/ } \\
\text { summer 2018) }\end{array}$ & Comments on 2017 & Comments on 2018 \\
\hline Sea ice concentration & $\%$ & $0-75$ & 0 & & \\
\hline Distance to sea ice edge & $\mathrm{km}$ & $0-50$ & $>50$ & & \\
\hline $\begin{array}{l}\text { Average mixed layer } \\
\text { thickness }\end{array}$ & $\mathrm{m}$ & $<10$ & $\gtrsim 50$ & $\begin{array}{l}\text { The meltwater resulted in a very } \\
\text { strong salinity stratification, hence } \\
\text { there was no real mixed layer }\end{array}$ & \\
\hline $\begin{array}{l}\text { Average productive } \\
\text { layer thickness }\end{array}$ & $\mathrm{m}$ & $\ll 30$ & $\gtrsim 50$ & Possibly in $\sim 10 \mathrm{~m}$ thin layers & $\begin{array}{l}\text { Inferred from less decline in } \\
\mathrm{AOU} \text { at } 55 \mathrm{~m}\end{array}$ \\
\hline Bloom start & & 10-May & 01-May & & \\
\hline Bloom end & & maybe 15 -Aug & 15-Jun & $\begin{array}{l}\text { Observations do not show a } \\
\text { classical bloom which crashes at a } \\
\text { certain time }\end{array}$ & $\begin{array}{l}\text { Bloom crashes as nitrate is } \\
\text { used up }\end{array}$ \\
\hline Bloom duration & months & $\sim 3$ & 1.5 & $\begin{array}{l}\text { Observations do not show a } \\
\text { classical bloom which crashes at a } \\
\text { certain time }\end{array}$ & \\
\hline $\begin{array}{l}\text { Maximum chlorophyll a } \\
\text { concentration }\end{array}$ & $\mathrm{gChl} \mathrm{m}-2$ & $\ll 0.12$ & $>0.3$ & $\begin{array}{l}\text { Based on upper range of chl satellite } \\
\text { values and } 30 \mathrm{~m} \text { productive layer }\end{array}$ & $\begin{array}{l}\text { Based on upper range of chl } \\
\text { sensor values at } 30 \mathrm{~m} \text { and } 50 \mathrm{~m} \\
\text { productive layer }\end{array}$ \\
\hline $\begin{array}{l}\text { Integrated apparent } \\
\text { oxygen } \\
\text { utilization (AOU) }\end{array}$ & $\mu \mathrm{mol} \mathrm{I}^{-1}$ & $(\sim-15)$ & $\sim-60$ & $\begin{array}{l}\text { Observations at } 30 \mathrm{~m} \text { are given in () } \\
\text { as they are below or at the very } \\
\text { bottom of the productive layer and } \\
\text { are therefore not representative of } \\
\text { the productive layer. Vertically } \\
\text { integrated values can therefore not } \\
\text { be calculated. }\end{array}$ & In productive layer \\
\hline $\begin{array}{l}\text { Maximum } \mathrm{pCO}_{2} \\
\text { drawdown }\end{array}$ & $\mu a t m$ & $(\sim 50)$ & $\sim 180$ & & \\
\hline $\begin{array}{l}\text { Integrated } \\
\text { carbon takeup }\end{array}$ & $\begin{array}{l}\mu \mathrm{mol} \mathrm{I}-1 \\
\mathrm{molC} \mathrm{m}^{-2} \\
\mathrm{gC} \mathrm{m}^{-2}\end{array}$ & $(\sim 17)$ & $\begin{array}{l}124 \\
6 \\
72\end{array}$ & & $\begin{array}{l}\text { In productive layer; } \\
\text { Vertically integrated over } 50 \mathrm{~m} \\
\text { productive layer }\end{array}$ \\
\hline Integrated nitrate takeup & $\mathrm{mol} \mathrm{m}^{-2}$ & $\ll 0.3$ & $>0.6$ & $\begin{array}{l}\text { No drawdown seen at } 30 \mathrm{~m} \text {; upper } \\
\text { bound estimated from nitrate } \\
\text { concentration at } 30 \mathrm{~m}\end{array}$ & $\begin{array}{l}\text { Lower bound due to likely } \\
\text { resupply by mixing }\end{array}$ \\
\hline $\begin{array}{l}\text { Net primary production } \\
\text { from nitrate takeup }\end{array}$ & $\begin{array}{l}\mathrm{molC} \mathrm{m}^{-2} \\
\mathrm{gC} \mathrm{m}^{-2}\end{array}$ & $\begin{array}{l}\ll 2.1 \\
\ll 25\end{array}$ & $\begin{array}{l}>4.2 \\
>50\end{array}$ & $\begin{array}{l}\text { Upper bound as mixing inhibited. In } \\
\text { addition: regenerated primary } \\
\text { production from ammonia (not } \\
\text { observed) }\end{array}$ & $\begin{array}{l}\text { Lower bound due to likely } \\
\text { resupply by mixing }\end{array}$ \\
\hline $\begin{array}{l}\text { Integrated export } \\
\text { measured by lander } \\
\text { trap over }\end{array}$ & $\mathrm{gC} \mathrm{m}^{-2}$ & $\begin{array}{l}1.3 \text { (Mar-Aug) } \\
2.1 \text { (Sep-Nov) }\end{array}$ & $\begin{array}{l}3.4 \text { (Mar-Aug) } \\
1.1 \text { (Sep-Nov) }\end{array}$ & & $\begin{array}{l}\text { September } 2018 \text { data is not } \\
\text { measured, but calculated as the } \\
\text { average of September values in } \\
2004-05,07-11,16-17 \text {. }\end{array}$ \\
\hline $\begin{array}{l}\text { Stoichiometry of } \\
\text { temporal evolution } \\
\text { of bloom }\end{array}$ & & & $\begin{array}{l}\left(7 \mu \mathrm{molO}_{2} \mathrm{I}^{-1}\right) / \\
\left(\left.1 \mu \mathrm{molNO}_{3}\right|^{-1}\right) \\
\left(0.6 \mu \mathrm{gChla}^{-1}\right) / \\
\left(\left.1 \mu \mathrm{molNO}_{3}\right|^{-1}\right)\end{array}$ & $\begin{array}{l}\text { Time series observations are not in } \\
\text { productive layer }\end{array}$ & $\begin{array}{l}\text { From daily average values in } \\
\text { productive layer O1May-15Jun }\end{array}$ \\
\hline $\begin{array}{l}\text { Phytoplankton carbon } \\
\text { per chlorophyll }\end{array}$ & $\begin{array}{l}\left(\left.\mu g\right|^{-1}\right) / \\
\left(\left.\mu g\right|^{-1}\right)\end{array}$ & & $6-60$ & & $\begin{array}{l}\text { Monotonically increases until } \\
\text { bloom crashes } 30\end{array}$ \\
\hline
\end{tabular}

(gray background shading in Figs. 4-6) of parameters contrasting the meltwater and mixed layer regimes at HG-IV. Depending on the parameter, its average, maximum, range, or temporal integral is given.

export event of $\sim 1 \mathrm{~g} \mathrm{~m}^{-2}$ of carbon $\left(\sim 30 \mathrm{mg} \mathrm{m}^{-2}\right.$ day $^{-1}$ resolved for $\sim 1$ month; Fig. $6 \mathrm{~d}$ ) arrived at the seafloor in $\sim 2600 \mathrm{~m}$ depth within 4-7 weeks after the onset of the bloom. Particle tracking in a numerical ocean model suggests the origin to be within $100 \mathrm{~km}$ horizontally ${ }^{38}$ and therefore presumably from upper ocean conditions as described above. The export event covered up to $45 \%$ of the seafloor area with green detritus material (Fig. 6e) suggesting pigmentation, i.e., high chlorophyll $a$ levels, and thus likely rich in nitrogen and other nutrients. The sedimented material included pteropod shells indicative that some grazing likely had taken place. This was a significant deposition of material on the seafloor, which appeared to be characterized by high nutritional quality that attracted benthic megafauna and fish in considerable numbers (5-fold rise; Fig. 6e) and caused a 50\% increase in benthic $\mathrm{O}_{2}$ consumption (Fig. 6d).

By mid June, i.e., within 1.5 months after the start of the bloom, nitrate in the productive mixed layer was depleted (Fig. 5e) with decreasing chlorophyll a concentrations in the euphotic zone (Fig. 5b) and increased light reaching $30 \mathrm{~m}$ depth (Fig. 5a). The system then transitioned to heterotrophic dinoflagellate dominance (data not shown), and nitrate, AOU, and $\mathrm{pCO}_{2}$ all increased, likely through remineralization and respiration, with Bacteroidetes continuing to account for a large proportion of the bacterial community (Fig. 6b).

Meltwater regime (spring/summer 2017). In 2017, ice export from the Arctic Ocean was enhanced and correspondingly ice cover and subsequent ice melt in Fram Strait were large. Thus the bloom phenology in the meltwater-stratified water column (MW regime) of the year 2017 was fundamentally different from the bloom phenology during the ML regime in 2018. The reduction of PAR at $30 \mathrm{~m}$ depth started later (mid May) and lasted only for about half a month (Fig. 5a), but was similar in amplitude to 2018. A reduction of PAR by one order of magnitude could be due to shadowing from ice if the open water fraction decreased by at least an order of magnitude, e.g., by a change from $0 \%$ to $>90 \%$ ice concentration. However, ice concentrations did not exceed $75 \%$ during the MW regime (Fig. 4a), and PAR at $30 \mathrm{~m}$ was reduced by almost 2 orders of magnitude (Fig. 5a). Hence, we conclude that the shadowing resulted from a phytoplankton bloom that took place in the water column above the sensor depth $(30 \mathrm{~m})$. This is corroborated by satellite observations of increased surface chlorophyll $a$ (Fig. 5b) and increased nitrite concentrations at $30 \mathrm{~m}$ during that period (Fig. 5e). 

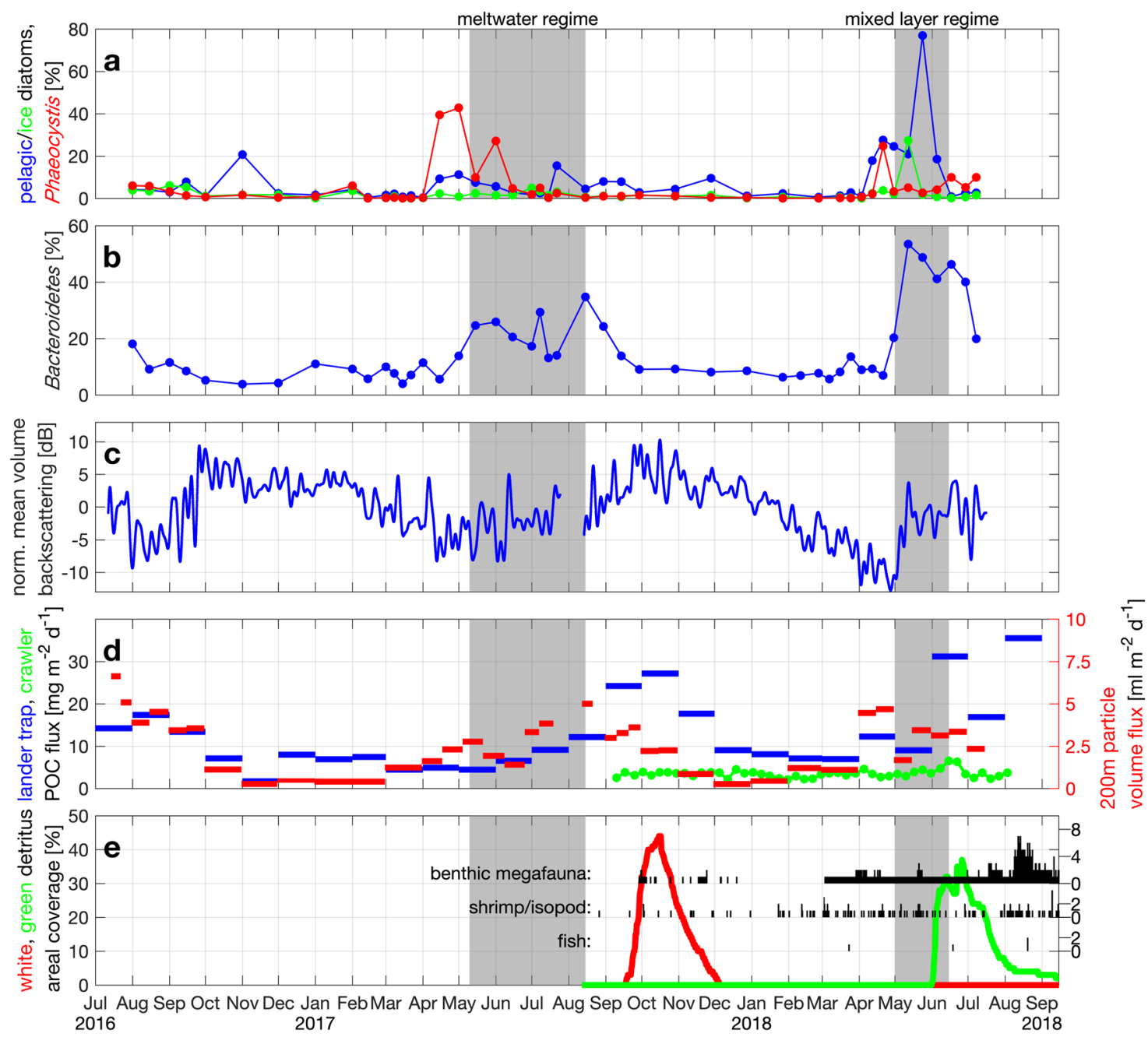

Fig. 6 Upper ocean biology, export, and benthic response at HG-IV. a Relative sequence abundances [\% eukaryotes] of pelagic (Thalassiosira and Chaetoceros; blue) and ice-associated (Fragilariopsis; green) diatoms and Phaeocystis (red) at $\sim 30 \mathrm{~m}$. b Relative sequence abundance [\% bacteria] of Bacteroidetes at $\sim 30 \mathrm{~m}$. c Normalized mean volume acoustic backscattering [dB] from $75 \mathrm{kHz}$ ADCP (blue) averaged over $50-100 \mathrm{~m}$ depth range as a proxy for zooplankton biomass; see Fig. S5 for a comparison to shallower reaching multi-frequency AZFPs. $\mathbf{d}$ Particulate organic carbon flux $\left[\mathrm{mg} \mathrm{m}^{-2} \mathrm{~d}^{-1}\right]$ from lander sediment trap at $2 \mathrm{~m}$ altitude (blue) and from benthic crawler Tramper's oxygen microprobe measurements at the seafloor (green); particle volume flux $\left[\mathrm{ml} \mathrm{m}^{-2} \mathrm{~d}^{-1}\right.$ ] from traps in $200 \mathrm{~m}$ depth (red). e Percentage of seafloor covered by fine white detritus (red) and coarser green detritus (green); number of epibenthic megafaunal organisms, shrimp/isopod, and fish in photos indicated as vertical black lines with separate $y$-scales on the right.

Considering the extremely strong stratification to within less than $5 \mathrm{~m}$ of the surface encountered in the shipboard observations (Fig. 3a, c), we infer that this early primary production resulting in substantial turbidity took place in a thin layer (possibly as thin as $10 \mathrm{~m}$ ) that limited light in the water below. A euphotic depth of $20 \mathrm{~m}$ is achieved by an average chlorophyll concentration of $4 \mathrm{\mu gl}^{-1}$ (as measured by the satellite, Fig. 5b) throughout the euphotic layer ${ }^{32}$. Considering that the satellite possibly underestimates the concentration below the surface and that it averages somewhat in space and time, $20 \mathrm{~m}$ is an upper bound on the euphotic depth supporting the speculation that the productive layer may have been as thin as $10 \mathrm{~m}$. We assume that when the nitrate was used up in the surface, the productive layer progressively moved downward but did not reach $30 \mathrm{~m}$. The biogeochemical measurements at $30 \mathrm{~m}$ only show a very small reduction in nitrate and silicate and little production of oxygen, highlighting the very shallow nature of the bloom in highly stratified surface waters and not reaching $30 \mathrm{~m}$. There is no reason to suspect that the nitrate concentration above $30 \mathrm{~m}$ was higher than at $30 \mathrm{~m}$. Hence, we take the $30-\mathrm{m}$ nitrate concentration and integrate it over the productive layer thickness to arrive at an upper bound on the column-integrated nitrate available for production in the highly stratified top layer; it could have sustained $<25 \mathrm{~g} \mathrm{~m}^{-2}$ of carbon (Table 1), i.e., less than half of what was available in the ML regime (2018). Furthermore, resupply by vertical mixing was very unlikely due to the strong stratification (Fig. S6). Note that the oxygen peak and $\mathrm{pCO}_{2}$ deficit of 10-12 of June 2017 (Fig. 5c, d) appear to be related to an advective event typical in the dynamic marginal ice zone ${ }^{21}$.

The water samples indicate that the bloom in the MW regime (2017) was dominated by Phaeocystis spp. with contributions of pelagic and ice-associated (Fragilariopsis) diatoms (Fig. 6a). Phaeocystis spp. can be positively buoyant 39,40 supporting its presence throughout the very top of the water column. Furthermore, it is known to form shallow blooms in the marginal ice zone $e^{41-43}$ and when not aggregated, its sinking speed is small $\left(0.1-2 \mathrm{~m} \mathrm{day}^{-1}\right)^{39}$. Since the water sampler was moored below the productive layer, we cannot quantify relative species abundance in the productive layer (Fig. 6a). Calanus finmarchicus dominated the biomass of the herbivorous zooplankton in the eastern Fram Strait ${ }^{44}$ but scarcely grazes on single cell Phaeocystis ${ }^{45}$. Consistently, a response in the zooplankton 

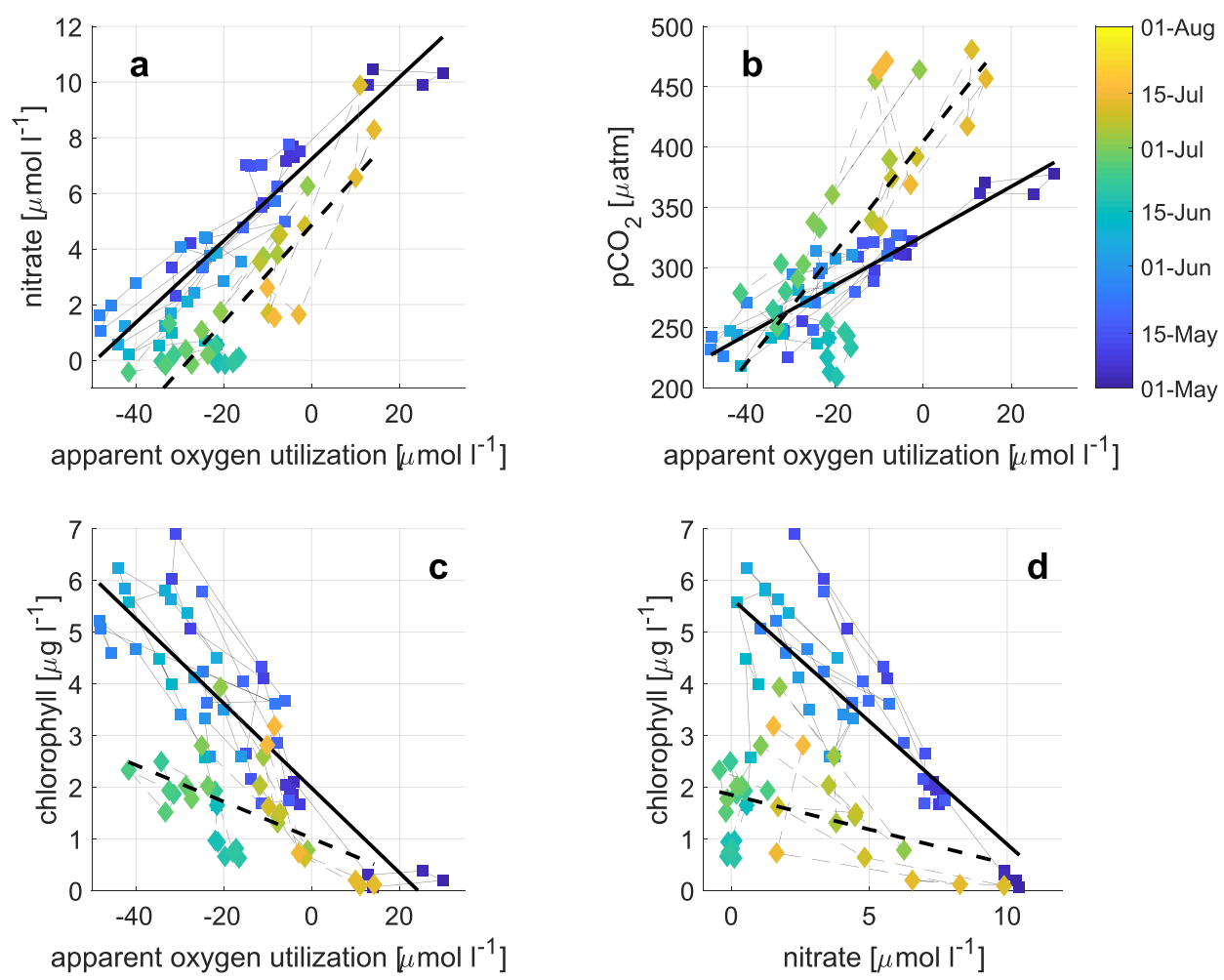

\begin{tabular}{|l|l|l|l|l|l|l|l|l|}
\cline { 3 - 9 } \multicolumn{4}{c|}{} & \multicolumn{3}{c|}{ 01-May to 15-Jun-2018 } & \multicolumn{3}{|c|}{ 15-Jun to 01-Aug-2018 } \\
\cline { 2 - 9 } \multicolumn{1}{c|}{$\mathrm{y}$} & $\mathrm{x}$ & $\mathrm{m}$ & $\mathrm{b}$ & $\mathrm{R}^{2}$ & $\mathrm{~m}$ & $\mathrm{~b}$ & $\mathrm{R}^{2}$ \\
\hline $\mathrm{A}$ & nitrate & AOU & 0.147 & 7.230 & 0.82 & 0.174 & 4.850 & 0.75 \\
\hline $\mathrm{B}$ & $\mathrm{pCO}_{2}$ & AOU & 2.040 & 326 & 0.81 & 4.570 & 405 & 0.52 \\
\hline $\mathrm{C}$ & chlorophyll & AOU & -0.082 & 1.980 & 0.70 & -0.035 & 1.010 & 0.27 \\
\hline $\mathrm{D}$ & chlorophyll & nitrate & -0.477 & 5.650 & 0.62 & -0.134 & 1.850 & 0.15 \\
\hline
\end{tabular}

Fig. 7 Stoichiometry of bloom in mixed layer regime. Scatter plots of daily averages of apparent oxygen utilization (AOU) $\left[\mu \mathrm{mol} \mathrm{I}^{-1}\right]$, nitrate $\left[\mu \mathrm{mol} \mathrm{I}^{-1}\right]$, $\mathrm{pCO}_{2}[\mu \mathrm{atm}]$, and chlorophyll $\left[\mu \mathrm{g} \mathrm{I}^{-1}\right]$ colored by date in 2018 at HG-IV. a Nitrate vs. AOU, b $\mathrm{pCO}_{2}$ vs. AOU, c chlorophyll vs. AOU, and d chlorophyll vs. nitrate. Colored squares are data between 01-May-2018 and 15-Jun-2018 during the spring bloom. The squares are connected by gray solid lines. A leastsquares regression curve is plotted as a solid black line for the time period and the regressions' parameters for the model $y=m \times x+b$ are given in the table at the bottom for the different parameter relations and time periods. Colored diamonds/dashed lines are the same for the time period after the bloom (15-Jun-2018 to 01-Aug-2018). Note that this analysis could not be done in 2017 as the observations were below the productive layer and no nitrate and chlorophyll observations exist.

biomass to the Phaeocystis bloom was not detected (Fig. 6c), suggesting that grazing was weak and zooplankton did not act as a quick export vector. Correspondingly, relative sequence abundances of copepods (not shown) increased in June to August, i.e., after the initial bloom. Vertical particle flux throughout the water column was small in May-June 2017 and the flux maxima at $200 \mathrm{~m}$ and $1200 \mathrm{~m}$ depth were not reached until mid August 2017 (Fig. 6d), i.e., 2 months later than during 2018.

This regenerative system within the stratified layer during 2017 retained the production in the upper ocean for $\sim 4$ months (Fig. 6d), likely supporting recycling in the pelagic ecosystem. Peak export arrived at the seafloor in September-November 2017 (Fig. 6d), i.e., $~ 3$ months later than in 2018. Up to $35 \%$ of the area was covered by pale-white material (Fig. 6e) characteristic of substantially aged material ${ }^{46}$. Emiliania huxleyi accounted for $<1 \%$ of sequences at $30 \mathrm{~m}$ (not shown), and pteropod aragonite typically dissolves before reaching $2000 \mathrm{~m}$ depth, suggesting that these factors did not significantly contribute to vertical flux. Melosira arctica, which when white in color is aged and nutrient poor ${ }^{47}$, contributed to the white material as seen under the microscope from the lander trap. However, irrespective of what exactly constituted the pale material, its lack of color suggests that labile photosynthetic pigments had been degraded, and the material itself was of highly degraded nature and thus low nutritional quality. This interpretation is supported by the fact that this export event did not elicit a comparable benthic response (one individual megafauna organism present, no change in oxygen consumption; Fig. 6d, e).

\section{Discussion}

In contrast to upper water column oceanography encountered in temperate or tropical open ocean regions, it is the peculiarities of meltwater-induced salinity stratification that are key to the dynamics of the Arctic Ocean. Meltwater can lead to very strong salinity stratification, comparable to the situation in river plumes ${ }^{48}$, and it can set in rapidly. Accordingly, our moored observations have recorded the transition from a $>300 \mathrm{~m}$ deep mixed layer to a thin mixed layer ( $<30 \mathrm{~m}$ thickness) in less than a month by meltwater effects. Later in the season, the shipboard observations showed stratification to within $5 \mathrm{~m}$ of the surface 
MELTWATER REGIME

Ice melt in location

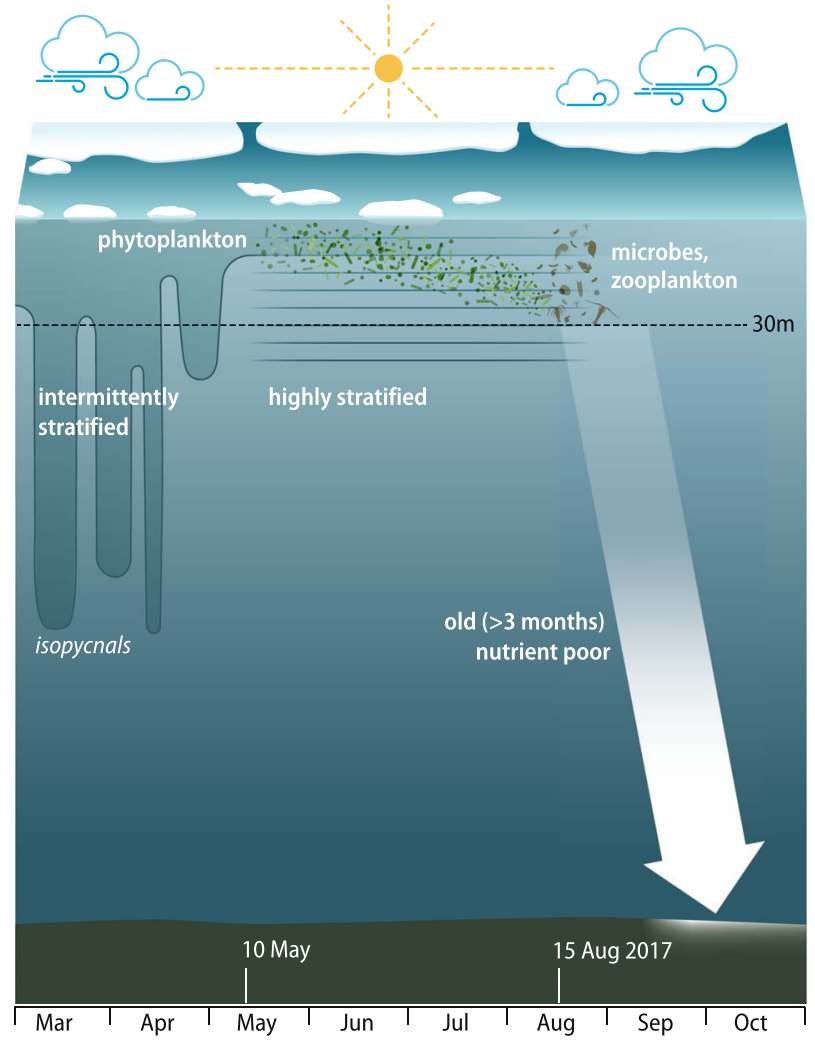

MIXED LAYER REGIME

Ice melt some distance away

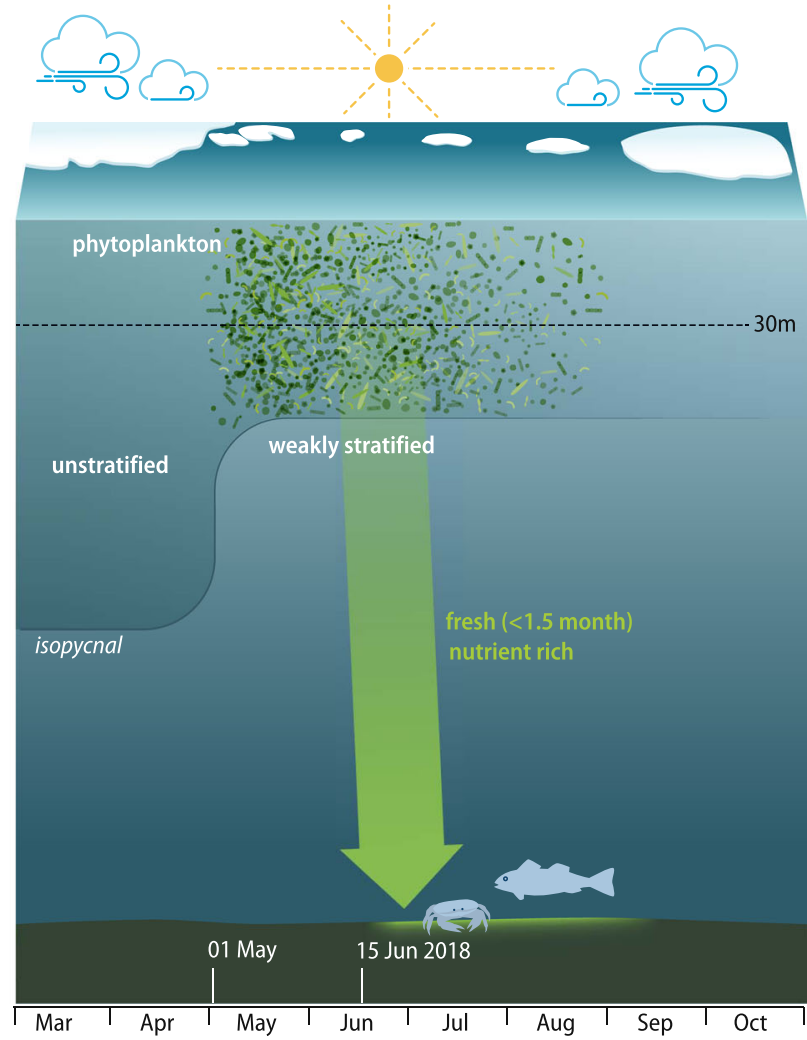

Fig. 8 Schematic contrasting the Meltwater Regime (left) and the Mixed Layer Regime (right). The dashed line at $30 \mathrm{~m}$ indicates the primary depth of our physical-biogeochemical observations. In addition, we had water column observations in 55 m, 265 m, ADCPs, sediment traps in 200 m and 1200 m, as well as and benthic observations (lander and crawler). We identified two types of surface stratification regimes that resulted in different bloom dynamics and different patterns and rates of carbon export (Table 1). Near-ice, meltwater-stratified waters (MW: meltwater regime observed in 2017 on left) hosted vertically constrained, longer duration blooms, while waters further from the ice edge (ML: mixed layer regime observed in 2018 on right) hosted higher biomass $\left(\mathrm{m}^{-2}\right)$ and shorter, more intense pulses of export carrying significant quantities of algal detritus to the seafloor, which supported higher megafauna densities.

(the mixed layer may have been even thinner than $5 \mathrm{~m}$ ) with a likely meltwater contribution of up to $1 / 6$ by volume. Temperature-driven stratification can typically not achieve such density differences and can therefore be more easily broken down intermittently by wind induced mixing ${ }^{49}$. The observed surface forcing by winds in 2017-2018 differed somewhat, but had no effect on the evolution of the mixed layer (Fig. S6).

We identified two types of surface stratification regimes that resulted in different bloom dynamics as summarized in Fig. 8 and, notably, different patterns and rates of carbon export (Table 1). Near-ice, meltwater-stratified waters (MW: meltwater regime) hosted vertically constrained, longer duration blooms, while waters further from the ice edge (ML: mixed layer regime) hosted higher biomass $\left(\mathrm{m}^{-2}\right)$ and shorter, more intense pulses of export carrying significant quantities of algal detritus to the seafloor, which supported higher megafauna densities. An additional mechanism that likely contributed to retaining the organic matter in the surface ocean in the MW regime is that sinking rates of aggregates are slowed by strong density gradients ${ }^{50}$. For the same density gradient, this effect is much stronger in a salinity stratified case because of the relatively slower diffusion of salt into aggregates $^{51}$. Our data suggest that it depends on the ice export through Fram Strait whether the hydrographic conditions in the Fram Strait marginal ice zone region follow the MW regime or the ML regime. The exact timing of the onset of the bloom in turn is determined by when the local heat flux turns positive such that deep winter mixing stops and stratification sets in ${ }^{52}$. According to ERA-Interim, this happened around May 8th with a standard deviation of 8 days between 2010 and 2018 .

Our conclusions are based on a temporally highly resolved continuous dataset, which together engender confidence in our description of the ecosystem phenology (i.e., temporal pattern of bloom development) and its drivers. Typical ship-based surveys often miss key transition moments in the system, such as the onset of the spring bloom or the summer/fall bloom in polar regions. Furthermore, the duration over which processes take place can be more fully assessed by autonomous observations that include in-situ estimates of rates and stoichiometries.

Between early March and late August (i.e., before the breakdown of stratification in fall), more than twice as much particulate organic carbon (POC) reached the seafloor in the ML regime than in the MW regime (Table 1). We note, however, that the majority of POC export in the MW regime occurred after early September (albeit visibly degraded), so the difference in POC export between early March and late November is small: only one third larger in the ML regime than the MW regime (Table 1) even though the nitrate availability was more than twice as large in the ML than the MW regime (Table 1). The BCP thus was more efficient in the MW regime than in ML regime, meaning that it exported more carbon per unit amount of nitrate exported at the 


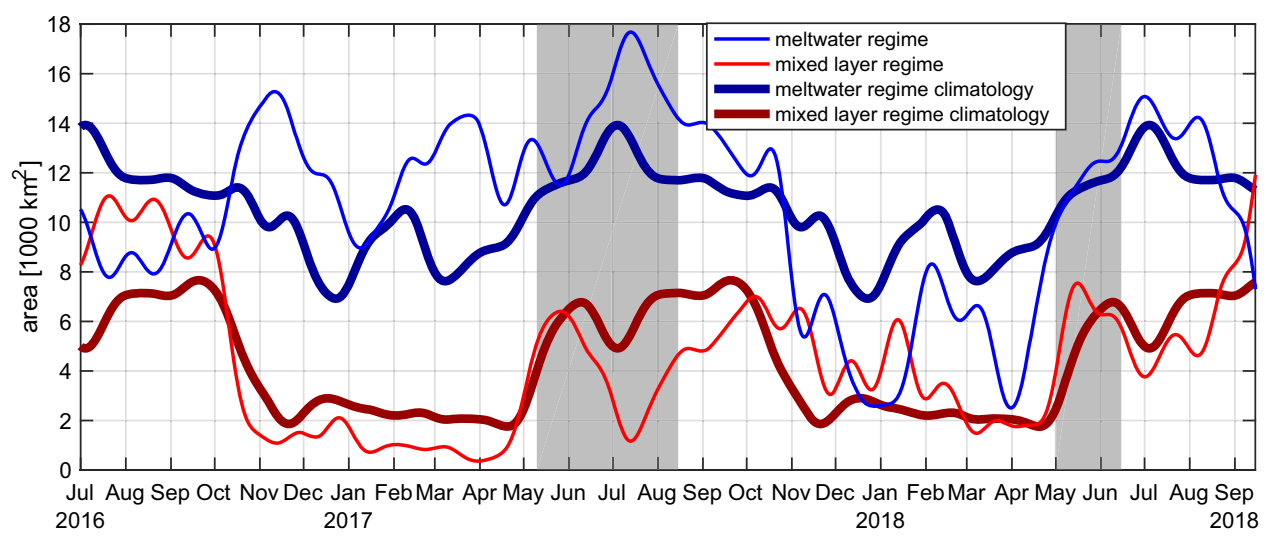

Fig. 9 Areal coverage of stratification regimes from the numerical ocean model. Area covered by different stratification regimes within the $18,500 \mathrm{~km}{ }^{2}$ large region $0^{\circ} \mathrm{E}-8^{\circ} \mathrm{E}, 78.5^{\circ} \mathrm{N}-79.5^{\circ} \mathrm{N}$ (see cyan box in Fig. 1). The meltwater regime's definition in the model is mixed layer depth MLD $<50 \mathrm{~m}$ and $\Delta \mathrm{S}>1$ (where $\Delta \mathrm{S}$ is salinity difference between the surface and $100 \mathrm{~m}$ depth). The mixed layer regime's definition is MLD $<50 \mathrm{~m}$ and $\Delta \mathrm{S}<1$. The meltwater regime is shown in blue with its climatology in dark blue; it is larger in spring/summer 2017 than typical. The mixed layer regime is shown in red with its climatology in dark red; it is somewhat larger than typical in spring/summer 2018. Unstratified (MLD > $50 \mathrm{~m}$ ) conditions make up for the rest of the areal coverage.

same time; the nutrients were likely retained in the surface ocean. However, our observations did not take account of the fate of direct sea ice algal production and export early in the year. It was previously observed that during ice melt, sinking velocities of POC and microbial connectivity are higher than in adjacent icefree waters ${ }^{53}$, but this does not hold more generally, in open waters where no ice is available to be melted or over the duration of the productive season ${ }^{40}$. The MW regime we have investigated here is characterized by the meltwater left behind by sea ice that has melted rather than by processes associated with ongoing sea ice melt, i.e., sea ice may no longer be present as it has either fully melted or has been advected out of the area, but the MW regime persists as long as the euphotic zone remains (strongly) salinity stratified.

Our data implies that the meltwater-stratified conditions (MW regime, 2017) favored the longer-term growth constrained within thin layers over multiple months, while the ice unaffected situation (ML regime, 2018) favored a short intense bloom that sank while still rich in chlorophyll, providing fresh labile organic carbon to the benthic ecosystem. In other words, the MW regime might be considered a retention system while the ML regime is more similar to an export system ${ }^{54-56}$ and the nature of the physical setting has a measurable impact on pelagic-benthic coupling.

The differences in bloom progression between the two years of observation point to large effects of ice advection (on the scale of $50 \mathrm{~km}$ ) on the local salinity stratification, ultimately impacting the ecosystem as a whole. We note that the bloom progression in the ML regime (2018) may be representative of future scenarios in the eastern Arctic Ocean subject to projected Atlantification ${ }^{57}$. In those scenarios, salinity stratification is reduced as sea ice may be increasingly absent, even in winter; alternatively, the sea ice and its associated meltwater could be advected out of the area such that the system is no longer directly impacted by ice. Conversely, the MW regime (2017) appears to be representative of blooms in low (but non-zero) ice concentration regions of the parts of the central Arctic Ocean that are covered by sea ice in winter. The sea ice melts prior to complete consumption of the nutrients in the productive layer in spring and produces very strong salinity stratification that cannot be overcome by wind mixing (except possibly for major storms that are not common in the area in summer).

Compared to the ML and MW regimes at mooring HG-IV described above, the variability during those two years observed
$55 \mathrm{~km}$ further east in purer Atlantic conditions (at mooring F4, Fig. 1, S1-S3) is intermediate with respect to most physical and biological parameters. Likewise, our MW and ML regime years represent the maximum and minimum, respectively, of the typical range of ice area export out of Fram Strait (Fig. 2). Based on results from an eddy-resolving sea ice-ocean model, we estimate that the area in Fram Strait covered by very strong meltwater stratification was almost $4000 \mathrm{~km}^{2}$ larger in spring/summer 2017 than its typical extent (Fig. 9) and it extended further to the east and south. Conversely, in spring/summer 2018 the ML regime covered an area $\sim 2000 \mathrm{~km}^{2}$ larger than typical. Hence, our two years of observations at HG-IV represent end points of the spectrum of the interannual and regional ice variability-and hence meltwater stratification-in this part of the Arctic Ocean up to now.

Climate change will substantially reduce the area covered by sea ice in summer, but in many parts of the Arctic the winter sea ice extent will probably be reduced much less. The seasonal ice zone, in which ice melts in spring and provides strong salinity stratification, could therefore actually become larger over time, increasing the spatial extent of the region experiencing dynamics similar to the MW regime described here. Furthermore, as ice becomes more mobile in the central Arctic, ice area export will likely increase further. However, the observed thinning of sea ice $^{58}$ may result in a decrease of the ice volume export ${ }^{26}$, meaning that at this stage it is not clear whether areas dominated by ice export such as central Fram Strait will experience an increase (like the MW regime) or decrease (like the ML regime) of the meltwater stratification.

Part of the Atlantic Water present near the surface in eastern Fram Strait subducts below Polar Water in the recirculation in central Fram Strait ${ }^{20}$. This AW then remains isolated from the atmosphere for a long time and partially crosses Denmark Strait to contribute to the formation of North Atlantic Deep Water ${ }^{59}$. Owing to their much larger salinity relative to the surface waters of the MW regime, the surface waters of the ML regime likely participate in this part of the physical carbon pump. This contribution to carbon sequestration needs to be considered in addition to the vertical carbon removal from the atmosphere through the biological carbon pump discussed above.

We note that sudden massive algal falls (of e.g., Melosira arctica) likely are rare in the region ${ }^{7,8,60}$ and therefore may only 
subsidize part of the annual benthic production. While the productivity of larger benthic organisms likely depends primarily on the integrated flux from pelagic blooms throughout the growth season, the quality of less degraded fast-sinking ice algal detritus may also play a role as has been shown in shallow Arctic areas ${ }^{61}$. The benthic community could benefit from an increased frequency of ML regimes, as long as diatoms are winners of the system, and provide intense, nutrient-rich pelagic export events ${ }^{62}$. Where diatoms are replaced by other phytoplankton groups which are not rapidly sinking, the higher productivity may not result in more export flux.

It has been predicted that primary productivity will increase in the future Arctic in most regions, but less so in Fram Strait ${ }^{63}$. Strong stratification in winter in the central Arctic limits nutrient resupply through deep winter mixing and the MW regime inhibits nutrient resupply to the euphotic zone during summer. The specific details of sea ice export, distribution, and melt will critically determine the net impact of global change on Arctic food webs including the benthic ecosystems and need further yearround observations.

\section{Methods}

Table S1 lists the data used in this paper, the instruments that it is based on, the data repositories, and in which figures the data are used.

\section{Global data sets}

Bathymetry. Bathymetric data was taken from the International Bathymetric Chart of the Arctic Ocean (IBCAO $30 \mathrm{sec}$ V3) 64 available at https://www.ngdc.noaa.gov/ $\mathrm{mgg} /$ bathymetry/arctic/grids/version3_0/.

Sea ice concentration. We use data derived from the Advanced Microwave Scanning Radiometer sensor AMSR-2 for the years 2013-18 processed in accordance with ${ }^{65}$ and downloaded from https://seaice.uni-bremen.de/sea-ice-concentrationamsr-eamsr2/66. At each grid point the sum of days during all April/May/June of 2013-2018 when the sea ice concentration at the grid point was $>20 \%$ was divided by the total number of days with data in those months to obtain the percentage of days with ice concentration $>20 \%$ (Fig. 1). For separate 7-day periods in April/ May/June 2017 and 2018 the mean ice concentration over those 7 days was calculated and the $20 \%$ contour of this mean was plotted separately for each of those 7-day periods. For each mooring and each day, the ice concentration at the grid cell closest to the mooring was calculated (Fig. 4a and S1a), and if the ice concentration at the mooring was below $20 \%$, the shortest distance to grid cells where the ice concentration exceeded $20 \%$ was calculated (Fig. $4 \mathrm{a}$ and S1a). If the ice concentration at the mooring exceeded $20 \%$, the shortest distance to grid cells where the ice concentration was below $20 \%$ was calculated and the distance was defined as negative.

Sea ice velocity and sea ice area export. Ice area flux estimates in Fig. 2a are calculated using CERSAT (Center for Satellite Exploitation and Research, France) motion estimates together with CERSAT ice concentration information ${ }^{67}$. Fluxes are estimated along a zonal gate positioned at $82^{\circ} \mathrm{N}$ between $12^{\circ} \mathrm{W}$ and $20^{\circ} \mathrm{E}$ and a meridional gate at $20^{\circ} \mathrm{E}$ between $80.5^{\circ} \mathrm{N}$ and $82^{\circ} \mathrm{N}$ (Fig. 1) for the period $1994-2020$ (January-May). The ice area flux at the gate is the integral of the product between the meridional and zonal ice drift and ice concentration. For a more detailed description we refer to ref. ${ }^{68}$. Arctic-wide sea ice velocity anomalies (Fig. 2b, c) were computed from the OSI-405-c motion product provided by the Ocean and Sea Ice Satellite Application 635 Facility (OSISAF) ${ }^{69}$.

Satellite chlorophyll. Surface chlorophyll concentrations measured with the Sentinel 3 A OLCI (Ocean and Land Colour Instrument) were downloaded from https:// earth.esa.int/web/sentinel/sentinel-data-access. The 8-day satellite data were averaged for the time series over grid points within boxes of $60 \mathrm{~km}$ by $60 \mathrm{~km}$ around the moorings.

Atmospheric reanalysis. ERA-Interim reanalysis ${ }^{70}$ data at the surface on a $0.25^{\circ}$ latitude by $0.25^{\circ}$ longitude grid at 12 hourly resolution was downloaded from https://apps.ecmwf.int/datasets/data/interim-full-daily/levtype=sfc/. Incoming shortwave radiation (ssr) and outgoing longwave radiation (str), sensible heat flux (sshf), and latent heat flux (slhf) were extracted and averaged to daily values.

\section{Physical numerical models}

FESOM. In this study, we used model data from the Finite-Element Sea ice-Ocean Model (FESOM) version 1.4 $4^{71}$. FESOM is a sea ice-ocean model that solves the hydrostatic primitive equations for the ocean and comprises a finite element sea ice component. It uses triangular surface meshes for spatial discretization, allowing for a refined mesh in regions of interest, while keeping a coarser mesh elsewhere. In the model configuration used here, a mesh resolution of nominally $1^{\circ}$ was applied in the global oceans. The mesh was refined to $25 \mathrm{~km}$ north of $40^{\circ} \mathrm{N}$, and to $4.5 \mathrm{~km}$ in the Nordic Seas and Arctic Ocean. In the wider Fram Strait $\left(20^{\circ} \mathrm{W}-20^{\circ} \mathrm{E} / 76^{\circ} \mathrm{N}-\right.$ $82^{\circ} 30^{\prime} \mathrm{N}$ ), the mesh was further refined to $1 \mathrm{~km}$. In this region, the simulation can be considered as eddy-resolving, as the local internal Rossby radius of deformation is about 2-6 $\mathrm{km}^{72,73}$. In the vertical, the model used $47 \mathrm{z}$-levels with a resolution of $10 \mathrm{~m}$ in the upper $100 \mathrm{~m}$, and coarser resolution with depth (with a resolution of $\sim 100 \mathrm{~m}$ at $800 \mathrm{~m}$ depth). For bottom topography, the RTopo-2 data set was used 74 . The model simulation covers the period 2010-2018 and has daily model output. It was forced with atmospheric reanalysis data from Era-Interim ${ }^{70}$, and was initialized with model fields from the simulation described in ref. ${ }^{75}$. River runoff (except for Greenland) was taken from the JRA-55 data set $^{76}$, and Greenland icesheet runoff was taken from ref. ${ }^{77}$. Tides were not taken into account in this simulation. Here we studied the model data of 2016 to 2018 in Fram Strait for comparison with our observations.

1-dimensional mixed layer depth model. The $\mathrm{PWP}^{78}$ 1-dimensional mixed layer model simulates the response of the ocean to surface fluxes. It ignores horizontal gradients and horizontal advection. This allows to judge whether certain surface flux conditions can on their own explain observed conditions. We ran the PWP model (as implemented for Matlab by http://www.po.gso.uri.edu/rafos/research/ pwp/) with four different scenarios (Fig. S6: P17-M17, P17-M18, P18-M17, P18M18) where: P17: An idealized initial profile based on the observed profiles (Fig. 3) representing the conditions in 2017: constant temperature of $2{ }^{\circ} \mathrm{C}$ in the vertical, linear salinity gradient from 30.5 at the surface to 35 at $50 \mathrm{~m}$ and another linear salinity gradient from 35 at $50 \mathrm{~m}$ to 35.1 at $200 \mathrm{~m}$. P18: An idealized initial profile based on the observed profiles (Fig. 3) representing the conditions in 2018: Same as P17 except that the surface to $50 \mathrm{~m}$ salinity gradient is from 34.8 to 35 . M17: A time series of the the meteorological forcing $(10 \mathrm{~m}$ wind velocity, heat fluxes, and evaporation minus precipitation) from the ERA-Interim reanalysis (Fig. $4 \mathrm{~b}$ ) at the grid point closest to mooring HG-IV for the period 15-May-2017 to 01-Aug-2017. M18: Same as M17 but for the period 15-May-2018 to 01-Aug-2018. M17 and M18 are provided in Supplementary Data 1.

Shipboard CTD data. Shipboard CTD casts of a standard dual sensor Seabird $911+$ CTD-rosette were occupied in spatial and temporal vicinity to the moored observations (Tab. S2) on three cruises: PS107 in 2017 (https://doi.org/10.1594/ PANGAEA.894189), PS114 in 2018 (https://doi.org/10.1594/PANGAEA.898694) of RV Polarstern, and JR17005 in 2018 (https://doi.org/10.5285/84988765-5fc25bba-e053-6c86abc05d53) of RRS James Clark Ross. The data were processed according to standard routine ${ }^{79}$. Additionally, we use underway CTD data from an OceanScience underway CTD collected during PS107 in 2017 (https://doi.org/ 10.1594/PANGAEA.886146) and processed according to ref. ${ }^{21}$.

Mooring data. The mooring data discussed in this paper is from two mooring clusters in the central and eastern Fram Strait (named "HG-IV" at $~ 79^{\circ} \mathrm{N} 4^{\circ} 20^{\prime} \mathrm{E}$ and "F4" at $\sim 79^{\circ} \mathrm{N} 7^{\circ} \mathrm{E}$ ) where moorings were located as close to each other as possible (the horizontal separation was equal to the water depth) in order to enable more measurements than could be fit physically onto a single mooring. Tab. S2/S3 list the deployment and recovery details of the moorings including the exact latitudes/longitudes as well as the individual instruments on the moorings. Note that all data shown in this paper from $\sim 30 \mathrm{~m}$ depth and the temperature/salinity/oxygen data from $\sim 55 \mathrm{~m}$ is from the HG-IV-S-* and F4-S-* moorings, while all other data is from the HG-IV-FEVI-* and F4-* moorings. The AZFP data is from F5-17 located roughly half way between the two clusters. All sensor based mooring raw data (except for the ASL AZFP data) is available at ref. ${ }^{80}$.

It is known that conversion factors for biogeochemical sensors (e.g., chlorophyll fluorescence) change over the seasons, depths, and regions ${ }^{81,82}$. In order to make as few assumptions as possible, we used the following approach: we could have determined the conversion factors from the instance when the ship was there with the CTD-rosette, but these conversion factors might not be appropriate for the majority of the time series. Hence, simply using the manufacturers' calibrations, as we do here, introduces fewer uncertainties. Where we have different estimates of the same parameter, we present them together and demonstrate that they agree qualitatively and also mostly quantitatively (e.g., Fig. 5b). In particular the timing of events is robust.

At some locations, the target variables were not measured the whole time or the measurements failed, hence we present what is available. The vertical location of the instruments (Fig. $4 \mathrm{c}$ and S1c) varied substantially (intermittently up to $200 \mathrm{~m}$ ) as a result of mooring blow downs caused by strong intermittent ocean currents. Time series have not been corrected for this vertical motion, but data are not used during blow downs in order not to bias the time series interpretation by temporal changes introduced by instruments traversing through vertical property gradients.

Physical sensor measurements. The physical sensors (for pressure, temperature, conductivity, and oxygen) were pre-cruise manufacturer calibrated and processed similar to ref. ${ }^{83}$; the processed data is also available at ref. ${ }^{80}$. 
Mixed layer depth $(M L D)$. Since there are no autonomous vertically profiling measurements available, we can only determine the minimum value of the mixed layer depth. At each hourly time step, the potential density difference $(\Delta \sigma)$ between the uppermost $(\sim 30 \mathrm{~m})$ temperature/salinity recorder and the underlying temperature/salinity recorders is calculated. The $0.5^{\text {th }}$ percentile of each $\Delta \sigma$ time series is added to the $\Delta \sigma$ time series for the different deployments. This fixes slight offsets in the temperature and/or conductivity calibrations which result in too negative or too positive density differences. The minimum estimate of the mixed layer depth at hourly resolution is then determined as the depth of the deepest instrument where $\Delta \sigma<0.05 \mathrm{~kg} \mathrm{~m}^{-3}$. If $\Delta \sigma>0.05 \mathrm{~kg} \mathrm{~m}^{-3}$ for all depths at a time step, then the minimum mixed layer depth can only be determined as 0 for that time step. Daily values of the MLD were defined as the depth at which three hourly realizations of MLD were shallower within a $24 \mathrm{~h}$ time span and at which the remaining $21 \mathrm{MLD}$ realizations were deeper. This biases the daily MLD estimate towards situations where phytoplankton is kept in the surface ocean rather than also being mixed down for some amount of time.

Stratification estimated between $30 \mathrm{~m}$ and $55 \mathrm{~m}$. Based on the temperature and salinity time series observed at $\sim 30 \mathrm{~m}$ and $\sim 55 \mathrm{~m}$, we estimate the buoyancy frequency as $N^{2}=\frac{-g}{\rho_{0}} \frac{\Delta \rho}{\Delta z}$ where $g$ is the acceleration due to gravity, $\Delta \sigma$ is the potential density difference over the vertical distance of $\Delta z=25 \mathrm{~m}$, and $\rho_{0}$ is the average density. The contributions to stratification due to temperature $\left(N^{2} \mathrm{~T}\right)$ and salinity $\left(N^{2}\right)$ are estimated as $N_{T}^{2}=g * \alpha \frac{\Delta T}{\Delta z}$ and $N_{S}^{2}=-g * \beta \frac{\Delta S}{\Delta z}$, respectively, where $\Delta T /$ $\Delta S$ are the temperature/salinity differences and $\alpha / \beta$ are the thermal expansion/ haline contraction coefficients estimated from the average temperature/salinity at the two measurement depths.

Apparent oxygen utilization (AOU). Oxygen concentration from the microcats was calculated using the pre-cruise manufacturer calibrations. AOU was calculated as the atmospherically equilibrated oxygen concentration (calculated from measured pressure, temperature, and salinity with sw_satO2 from the Seawater toolbox available at http://www.cmar.csiro.au/datacentre/ext_docs/seawater.htm) minus the measured oxygen concentration.

\section{Light}

Polar night/polar day. The length of day (hours per $24 \mathrm{~h}$ that the sun is above the horizon) was calculated from the sunrise equation as implemented for Matlab by https://de.mathworks.com/matlabcentral/fileexchange/55509-sunrise-sunset.

Photosynthetically available radiation (PAR). The WetLabs Eco PAR measured PAR for 5 (in 2016-2017) or 10 (in 2017-2018) individual measurements $1 \mathrm{~s}$ apart from each other before it slept for $1 \mathrm{~h}$ before repeating the measurement cycle. These 5 or 10 individual measurements are averaged linearly to obtain hourly values at $\sim 30 \mathrm{~m}$ depth (Fig. 5a blue). Values below the detection limit are set to a constant of $10^{-1.32} \mu \mathrm{mol} \mathrm{m}-2 \mathrm{~s}^{-1}$. Hourly values are linearly averaged to daily values (Fig. 5a black). The incoming solar shortwave radiation varies as a function of season and latitude as well as cloud cover as represented in the ERAInterim reanalysis (parameters ssr). Its unit of $\mathrm{W} \mathrm{m}^{-2}$ is converted to PAR assuming a constant spectral distribution as $1 \mathrm{~W} \mathrm{~m}^{-2}=2.1 \mu \mathrm{mol} \mathrm{m}^{-2} \mathrm{~s}^{-184}$. In order to compare the PAR measured at a depth of approximately $30 \mathrm{~m}$ to the surface values, we approximate a spectrally averaged diffuse attenuation coefficient for PAR in clear water using the values of ${ }^{85}$ as $k_{\mathrm{d}}=0.02 \mathrm{~m}^{-1}$ and apply it to calculate a constant exponential extinction applied to the reanalysis surface values (Fig. 5a yellow). The average PAR available $\left(P A R_{\text {available }}\right)$ to phytoplankton being moved around in the clear water mixed layer of depth $M L D$ was calculated as the depth averaged vertical integral of the clear water extinguished PAR at the surface ( $P A R_{\text {surf }}$ from the shortwave radiation of ERA-Interim): $P A R_{\text {available }}=\frac{1}{M L D} * \int_{z=0}^{z=M L D} P A R_{\text {surf }} * e^{-k_{d} z} d z$ (Fig. 5a red).

\section{Chlorophyll concentration and optical backscattering}

Chlorophyll fluorescence. The WetLabs ECO Triplet measures fluorescence at a "chlorophyll wavelength" and at a "CDOM wavelength" as well as optical scattering at $700 \mathrm{~nm}$. The conversion from fluorescence to chlorophyll $a$ concentration (in $\mu \mathrm{gl}^{-1}$ ) follows a manufacturer determined conversion determined for a monoculture of phytoplankton (Thalassiosira weissflogii), which typically overestimates the chlorophyll concentration. Hence, we applied the community-established calibration bias of 2 for the WetLabs ECO-series fluorometer to these in situ fluorometric chlorophyll values ${ }^{81}$. This conversion factor may be different in ocean waters of Fram Strait, but it still gives reasonable agreement with independent estimates.

Optical backscattering. The EcoTriplet measured 8 individual measurements $1 \mathrm{~s}$ apart from each other before it slept for $1 \mathrm{~h}$ before repeating the measurement cycle. For the chlorophyll fluorescence, the individual measurements are averaged to hourly values. For the scattering, times when individual 1-second measurements exceed $0.002 \mathrm{~m}^{-1} \mathrm{sr}^{-1}$ are indicative of strong optical backscattering not due to small particles in the water column, but rather to larger potentially aggregated particles. The times of strong backscattering are marked individually (Fig. 5b red).

\section{Nutrients}

Nitrate (SUNA sensor). Prior to deployment (11 and 15 days for sensors deployed at HG-IV and F4, respectively), the reference spectrum of the sensors were updated as per manufacturer specifications. We first let the sensors cool down for $24 \mathrm{~h}$ at $0^{\circ} \mathrm{C}$ in a temperature controlled laboratory. Next, the reference spectrum update was achieved by measuring Milli- $Q$ water (i.e., no nitrate present). To verify if this update was successful, solutions with three different nitrate concentrations $(3,7$, and $14 \mu \mathrm{moll}^{-1}$ ) were then measured, with the output being monitored live (expected to be within $\pm 2 \mu \mathrm{moll}^{-1}$ of each concentration). A measuring time of $20 \mathrm{~s}$ yields stable results and was thus applied during the deployments with an interval of $6 \mathrm{~h}$. Upon recovery, SUNA data were processed using the SeaBird UCI software package version 1.2.1. Here, temperature and salinity data were used to remove the spectrum of bromide and compensate for temperature dependent absorption using an algorithm developed by ref. ${ }^{86}$. This step yields the spectrum of nitrate only, at a precision of $\pm 0.3 \mu \mathrm{mol}^{-1}$. The sensor is characterized by a drift of $0.3 \mu \mathrm{moll} \mathrm{l}^{-1}$ per hour lamp time. Given the deployment settings, a total operational time of about $8 \mathrm{~h}$ was accumulated. Therefore, a linear drift correction of $2.4 \mu_{\mathrm{mol}} \mathrm{l}^{-1}(365 \text { days })^{-1}$ was applied. Up to this point, however, accuracy remains at $2 \mu \mathrm{moll}^{-1}$ as per manufacturer specifications. Therefore, an offset correction is then applied based on the in situ concentrations observed at the beginning of the deployment as well as with the RAS (see below) where available, with outliers excluded.

Inorganic nutrients from Remote Access Samplers (RAS). McLane RAS were programmed to draw two $500 \mathrm{ml}$ samples ( $1 \mathrm{~h}$ apart, starting at noon) approximately every other week. Samples within the RAS were collected in sterile plastic bags and fixed with $700 \mu \mathrm{l}$ of $50 \%$ mercuric chloride solution. Upon recovery, two samples from a given sampling date were combined to yield a volume of 11 , required for bacterial and phytoplankton genetic analyses (see below), and a 50-ml aliquot destined for the measurement of dissolved inorganic nutrients. Aliquots for nutrient analysis were collected in PE bottles, which were then stored frozen $\left(-20^{\circ} \mathrm{C}\right)$ until analysis on land. Analyses for inorganic nutrients were carried out using a QuAAtro Seal Analytical segmented continuous flow autoanalyser following standard colorimetric techniques. The accuracy of the analysis was evaluated through the measurement of KANSO LTD Japan Certified Reference Materials and corrections were applied accordingly. Finally, we evaluated pressure, temperature, and salinity data from the CTD (SBE37-SMP-ODO) attached to the RAS to determine whether the two samples taken one hour apart on a given date drew water from the same depth and with consistent properties.

\section{Carbonate system}

$\mathrm{pCO}_{2}$ and $\mathrm{pH}$. The calibration of SAMI $\mathrm{pH}$ and SAMI CO2 sensors was carried out by the manufacturer, approximately 2 months prior to deployment. The calibration certificates specify accuracy and precision of $\pm 0.003 / \pm 0.001 \mathrm{pH}$ units and \pm 3 / $<1 \mu \mathrm{atm}$, respectively. $\mathrm{pCO}_{2}$ sensors measure and yield $\mathrm{pCO}_{2}$ in $\mu$ atm. For the $\mathrm{pH}$ sensor, raw absorption data were converted to $\mathrm{pH}$ (total hydrogen ion scale) in combination with temperature and salinity (SBE37-SMP-ODO) using the quality control tool (QC_pH) supplied by the manufacturer.

Upon assessment of $\mathrm{pCO}_{2}$ data, values from the HG-IV mooring in 2017-2018 were deemed to be biased high by approximately $130 \mu$ atm (with a step jump at the turn-around of the moorings), therefore a constant value of this magnitude was subtracted from that record. The $\mathrm{pH}$ sensors ran out of battery towards the end of the deployments, resulting in interrupted records. At HG-IV, some erratic data before the sensors stopped recording were excluded for the first deployment after 16-Feb-2017 and for the second deployment after 02-Aug-2018. At F4 in $2017-2018 \mathrm{pH}$ values below 8 were excluded.

Carbon takeup is estimated from the change in dissolved inorganic carbon (DIC) between the beginning of the bloom and the time when the minimum $\mathrm{pCO}_{2}$ is reached. In turn, DIC is calculated from $\mathrm{pCO}_{2}$ and alkalinity ${ }^{87}$ as well as measured temperature, measured salinity, phosphate concentration $\left(0.5 \mu \mathrm{mol} \mathrm{l}^{-1}\right)$, and silicate concentration $\left(5 \mu \mathrm{moll}^{-1}\right)$. Alkalinity is taken from the relationship Alk $=736+45.2 * \mathrm{~S}$ in ref. ${ }^{88}$.

\section{Microbial communities}

Relative abundances of bacteria and microbial eukaryotes based on $16 \mathrm{~S}$ and $18 \mathrm{~S}$ rRNA gene sequences. The methodology followed ${ }^{89}$ which we briefly summarize here: the same water samples as for the inorganic nutrients (see above) were used, in which mercuric chloride resulted in fixation of microbes for long-term preservation ${ }^{90}$. After recovery, the $\sim 11$ per sampling event was immediately filtered through $0.22 \mu \mathrm{m}$ Sterivex filter cartridges (Millipore, Burlington, MA). Filters were immediately frozen at $-20^{\circ} \mathrm{C}$ until DNA extraction in the home laboratory.

DNA was extracted using the DNeasy PowerWater kit (Qiagen, Germany) according to the manufacturer's instructions and quantified using a Quantus fluorometer (Promega, Madison, WI). Obtained DNA quantities ranged between 0.01 and $11 \mathrm{ng}(\mu \mathrm{l})^{-1}$. Bacterial $16 \mathrm{~S}$ and eukaryotic $18 \mathrm{~S}$ rRNA gene fragments were amplified using primers $515 \mathrm{~F}-926 \mathrm{R}^{91}$ and $528 \mathrm{~F}-964 \mathrm{i}^{92}$, respectively, according to the $16 \mathrm{~S}$ Metagenomic Sequencing Library Preparation protocol (Illumina, San Diego, CA). Amplicon gene libraries were sequenced using Illumina MiSeq instruments at CeBiTec (Bielefeld, Germany; bacteria) or AWI (eukaryotes). After primer removal using cutadapt $\mathrm{t}^{93}$ reads were classified into amplicon sequence variants (ASVs) using DADA2 ${ }^{94}$. 
After singleton removal, we obtained a mean of 60,000 bacterial and 119,000 eukaryotic reads per sample that sufficiently covered community composition ${ }^{89}$. Bacterial and eukaryotic reads were taxonomically classified using the Silva v138 and $\mathrm{PR}^{2}$ v4.12 databases, respectively.

\section{Normalized mean volume backscattering (MVBS) as proxy for zooplankton biomass}

MVBS. RDI Workhorse Longranger ADCPs were deployed, using a four-beam, convex configuration with a beam angle of $20^{\circ}$ and frequencies of $76.8 \mathrm{kHz}$. The number of bins was set to 70 with a bin length of $8 \mathrm{~m}$. The sampling interval was set to 20 pings per ensemble with a ping rate of about 20 pings every $60 \mathrm{~min}$. The instruments were moored at a nominal depth of $\sim 400 \mathrm{~m}$ in upward-looking mode and measured horizontal and vertical currents and acoustic backscatter intensity. Instrument heading, pitch and roll and temperature data were also collected. The echo intensities were given in an automatic gain control count scale of 0 to 255 . Following ${ }^{95}$, they were converted to MVBS. We used beam-averaged data because the four beams together gave a better signal-to-noise ratio than individual beams. First, the noise level of all four ADCP beams was determined from the minimum values of RSSI (Received Signal Strength Indicator) counts obtained in the remotest depth cell, when the sea surface was outside the ADCP range. Sound velocity $c$ and sound absorption coefficient $a$ were considered variable with depth and time and calculated according to the UNESCO formulas from an interpolation in time of 2 CTD profiles collected at the beginning and the end of the deployment. The mean at each depth for the 20 single pings comprising an hourly burst was calculated.

An ASL Acoustic Zooplankton Fish Profiler (AZFP) was moored at F5 $\left(79^{\circ} \mathrm{N}\right.$, $5^{\circ} 40^{\prime} \mathrm{E}$ ) with the transducer faces pointing upward in $\sim 150 \mathrm{~m}$ depth and operated at four different frequencies $(38,125,200$ and $455 \mathrm{kHz})$. The sampling interval was set to $30 \mathrm{~s}$ with a pulse duration of $0.5 \mathrm{~ms}(38 \mathrm{kHz})$ and $0.17 \mathrm{~ms}(125 \mathrm{and} 200 \mathrm{kHz})$, respectively. Pitch and roll were measured with each ping. Data from the $455 \mathrm{kHz}$ transducer were omitted from this analysis. AZFP data were post-processed and integrated with Echoview software version 11.0.239 (Echoview Software Pty Ltd, Hobart, Australia). Background noise was removed through time-varied thresholds for each transducer, and after removing noise and unwanted signals originating from e.g., other mooring devices that temporally became visible as backscatter in the echograms, the MVBS was integrated and exported for 24-hr bins.

For both ADCP and AZFP data the $50-100 \mathrm{~m}$ vertical average was calculated and for the AZFP also the $15-100 \mathrm{~m}$ and $30-100 \mathrm{~m}$ vertical averages. The median for each mooring deployment of the daily mean values of the vertical MVBS means was calculated. This median was subtracted from the MVBS to obtain the normalized MVBS, which corrects for possible hardware differences between the different deployments ${ }^{96}$.

Note that no AZFPs existed at moorings HG-IV and F4 and the ADCPs did not return data shallower than $50 \mathrm{~m}$. Therefore, we use the comparison in Fig. S5 to show that the ADCPs deliver similar qualitative statements compared to the shallower reaching multi-frequency AZFPs. Apart from one exception, there are no large qualitative differences between the averaging in the different depth layers. That means that, most of the time, observations between $50-100 \mathrm{~m}$ do not miss a large part of the biomass. The exception occurred in August 2017 when the biomass above $30 \mathrm{~m}$ appeared to be much stronger. Likewise, there were no qualitative differences in the progression of the curves between the different frequencies. Therefore, the 50-100 m ADCP appears to be a reasonable proxy of zooplankton and fish biomass and we use it at HG-IV and F4 (Fig. $6 \mathrm{c}$ and S3c).

\section{Particle and POC flux}

Sediment volume flux in water column. Sediment traps were located $200 \mathrm{~m}$ and $1200 \mathrm{~m}$ below the sea surface at mooring HG-IV and at $200 \mathrm{~m}$ at mooring F4. The collector cup opening times ranged from 9 to 59 days depending on the season (lower resolution in winter). The cups had an interior diameter of $4 \mathrm{~cm}$ and the height of the sedimented layer on the bottom was measured from photos of the cups. From these the sediment volume was calculated and it was normalized by the $0.5 \mathrm{~m}^{2}$ collection area and the opening duration. We assume that this sediment volume flux is approximately proportional to total particulate matter (i.e., POC and lithogenic matter) flux and use it only to infer qualitative differences and the timing of events.

POC flux from sediment trap on bottom lander. Aliquots of the sedimented material collected at $2.5 \mathrm{~m}$ above the seafloor in sediment traps on the bottom lander at HGIV were sieved through $500-\mu \mathrm{m}$ mesh size to remove larger zooplankton swimmers or benthic organisms, then filtered on pre-combusted Whatman GF/F glass fiber filters, acidified with $0.1 \mathrm{~N} \mathrm{HCl}$, and dried at $60^{\circ} \mathrm{C}$. POC concentrations were determined with a CaloErba $\mathrm{CN}$-analyzer. These were then normalized by the split factor as well as to the $0.25 \mathrm{~m}^{2}$ collection area and the cup opening duration. As the sediment trap was deployed $2.5 \mathrm{~m}$ above the bottom, it also collected resuspended material in addition to settling material.

POC flux inferred from benthic oxygen consumption. Benthic carbon mineralization was estimated from sediment oxygen consumption rates. The benthic crawler called TRAMPER ${ }^{97}$ was deployed at HG-IV for one year and moved $15 \mathrm{~m}$ along the seafloor every 7 days. Upon arriving at the new location, it measured oxygen concentration profiles through the top $15 \mathrm{~cm}$ of the sediment. From the shape of the oxygen profile, the benthic oxygen consumption, i.e., the oxygen flux from the water column into the sediment was calculated. Assuming a Respiratory Quotient of 1.0 (i.e., that $\mathrm{O}_{2}$ consumed via benthic diagenesis is balanced by a corresponding molar production of $\mathrm{CO}_{2}$ ) oxygen consumption rates were converted to POC fluxes reaching the benthos.

\section{Seafloor imagery}

Detritus seafloor areal coverage. An underwater camera (VTLC: Video Time Lapse Camera; AquaPix, USA) fitted to a benthic lander at HG-IV took 5-second video sequences twice a day for the 2017-2018 deployment year. Frame grabs were extracted and divided into 100 boxes referring to equal sized areas of the seafloor. At each time, the number of boxes covered by bare seafloor, by accumulating small white material, and green material was calculated. The white material, though very fine in size, accumulated over a larger area of seafloor than the much more massive green material identified as algal detritus. This is presumably related to hydrodynamics associated with the microtopography of the seafloor.

Number of megafauna present. All eelpout fish (Lycodes frigidus) and visible epibenthic megafauna including shrimps (Bythocaris spp), isopods (Saduria megalura), holothurians (Kolga hyalina), and gastropods (Mohnia spp.) observed in each frame grab were counted. Additionally, at the very bottom edge of the screen a purple sea anemone and branches of the sponge Cladorhiza gelida were present, but not included in the data.

\section{Data availability}

Data are freely available online at references ${ }^{98-104}$ and at the links given in Table S1 or are provided in the supplementary materials file Supplementary_Data_1.xlsx.

Received: 28 May 2021; Accepted: 28 October 2021; Published online: 15 December 2021

\section{References}

1. Strass, V. H. \& Nöthig, E.-M. Seasonal shifts in ice edge phytoplankton blooms in the Barents Sea related to the water column stability. Polar Biol. 16, 409-422 (1996).

2. Janout, M. et al. Sea-ice retreat controls timing of summer plankton blooms in the Eastern Arctic Ocean. Geophys. Res. Lett. 43, 1-9 (2016).

3. Mayot, N. et al. Assessing phytoplankton activities in the seasonal ice zone of the Greenland sea over an annual cycle. J. Geophys. Res. 123, 8004-8025 (2018).

4. Sakshaug, E. \& Slagstad, D. Light and productivity of phytoplankton in polar marine ecosystems: a physiological view. Polar Res. 10, 69-86 (1991).

5. Leu, E., Søreide, J. E., Hessen, D. O., Falk-Petersen, S. \& Berge, J. Consequences of changing sea-ice cover for primary and secondary producers in the European Arctic shelf seas: timing, quantity, and quality. Prog. Oceanogr. 90, 18-32 (2011).

6. Wassmann, P. \& Reigstad, M. Future Arctic ocean seasonal ice zones and implications for Pelagic-Benthic coupling. Oceanography 24, 220-231 (2011).

7. Boetius, A. et al. Export of algal biomass from the melting Arctic sea ice. Science 339, 1430-1432 (2013).

8. Wiedmann, I. et al. What feeds the Benthos in the Arctic basins? Assembling a carbon budget for the deep Arctic ocean. Front. Mar. Sci. 7, 224 (2020)

9. Tremblay, J.-E. \& Gagnon, J. in Influence of Climate Change on the Changing Arctic and Sub-Arctic Conditions (Springer, 2009).

10. Codispoti, L. A. et al. Synthesis of primary production in the Arctic Ocean: III. Nitrate and phosphate based estimates of net community production. Prog. Oceanogr. 110, 126-150 (2013).

11. Mundy, C. J. et al. Contribution of under-ice primary production to an iceedge upwelling phytoplankton bloom in the Canadian Beaufort Sea. Geophys. Res. Lett. 36, (2009).

12. Sakshaug, E. The Organic Carbon Cycle in the Arctic Ocean Vol. 193 (Springer, 2004).

13. Mayot, N. et al. Springtime export of Arctic sea ice influences phytoplankton production in the Greenland sea. J. Geophys. Res. C 125, 261 (2020).

14. Lampe, V., Nöthig, E.-M. \& Schartau, M. Spatio-temporal variations in community size structure of Arctic protist plankton in the Fram Strait. Front. Mar. Sci. 7, 1239 (2020)

15. Friedlingstein, P. et al. Global carbon budget 2020.Earth Syst Sci. Data 12, 3269-3340 (2020)

16. Takahashi, T. et al. Climatological mean and decadal change in surface ocean pCO2, and net sea-air CO2 flux over the global oceans. Deep Sea Res. Part 2 Top. Stud. Oceanogr. 56, 554-577 (2009).

17. Landschützer, P. et al. A neural network-based estimate of the seasonal to inter-annual variability of the Atlantic Ocean carbon sink. Biogeosciences 10, 7793-7815 (2013). 
18. Soltwedel, T. et al. FRAM - FRontiers in Arctic marine Monitoring Visions for permanent observations in a gateway to the Arctic Ocean. in 2013 MTS/IEEE OCEANS - Bergen 1-7 (2013).

19. Beszczynska-Möller, A., Fahrbach, E., Schauer, U. \& Hansen, E. Variability in Atlantic water temperature and transport at the entrance to the Arctic Ocean, 1997-2010. ICES J. Mar. Sci. 69, 852-863 (2012).

20. Hattermann, T., Isachsen, P. E., von Appen, W.-J., Albretsen, J. \& Sundfjord, A. Eddy-driven recirculation of Atlantic Water in fram strait. Geophys. Res. Lett. 43, 1-9 (2016).

21. von Appen, W.-J. et al. Observations of a submesoscale cyclonic filament in the marginal ice zone. Geophys. Res. Lett. https://doi.org/10.1029/ 2018GL077897 (2018)

22. Steele, M. \& Ermold, W. Loitering of the retreating sea ice edge in the Arctic Seas. J. Geophys. Res. C 120, 7699-7721 (2015).

23. Joiris, C. R. \& Falck, E. Summer at-sea distribution of little auks Alle alle and harp seals Pagophilus (Phoca) groenlandica in the Fram Strait and the Greenland Sea: impact of small-scale hydrological events. Polar Biol. 34, 541-548 (2011).

24. Smedsrud, L. H., Halvorsen, M. H., Stroeve, J. C., Zhang, R. \& Kloster, K. Fram Strait sea ice export variability and September Arctic sea ice extent over the last 80 years. Cryosphere 11, 15 (2017).

25. Krumpen, T. et al. Arctic warming interrupts the Transpolar Drift and affects long-range transport of sea ice and ice-rafted matter. Scientific Reports 9 (2019).

26. Zamani, B., Krumpen, T., Smedsrud, L. H. \& Gerdes, R. Fram Strait sea ice export affected by thinning: comparing high-resolution simulations and observations. Clim. Dyn. 1-14 (2019).

27. Peralta-Ferriz, C. \& Woodgate, R. A. Seasonal and interannual variability of pan-Arctic surface mixed layer properties from 1979 to 2012 from hydrographic data, and the dominance of stratification for multiyear mixed layer depth shoaling. Prog. Oceanogr. 134, 19-53 (2015).

28. Osborne, E., Richter-Menge, J. \& Jeffries, M. Arctic report card 2018 (2018).

29. Tuerena, R. et al. An Arctic strait of two halves: the changing dynamics of nutrient uptake and limitation across the Fram Strait. Global Biogeochem Cycles, 35, https://doi.org/10.1029/2021GB006961 (2021).

30. Menge, M. Phytoplankton succession in the eastern Fram Strait (August 2017 - July 2018)-Microscopic analysis of autonomously collected water samples (University of Bremen, 2019).

31. Nöthig, E.-M. et al. Summertime chlorophyll a and particulate organic carbon standing stocks in surface waters of the Fram strait and the arctic ocean (1991-2015). Front. Mar. Sci. 7, (2020).

32. Morel, A. \& Berthon, J.-F. Surface pigments, algal biomass profiles, and potential production of the euphotic layer: relationships reinvestigated in view of remote-sensing applications. Limnol. Oceanogr. 34, 1545-1562 (1989).

33. Cherkasheva, A., Nöthig, E.-M., Bauerfeind, E., Melsheimer, C. \& Bracher, A. From the chlorophyll-a in the surface layer to its vertical profile: a Greenland Sea relationship for satellite applications. Ocean Sci. 9, 431-445 (2013).

34. Teeling, H. et al. Substrate-controlled succession of marine bacterioplankton populations induced by a phytoplankton bloom. Science 336, 608-611 (2012).

35. Falk-Petersen, S. et al. Lipid biomarkers and trophic linkages between ctenophores and copepods in Svalbard waters. Mar. Ecol. Prog. Ser. 227, 187-194 (2002).

36. Cleary, A. C., Søreide, J. E., Freese, D., Niehoff, B. \& Gabrielsen, T. M. Feeding by Calanus glacialis in a high arctic fjord: potential seasonal importance of alternative prey. ICES J. Mar. Sci. 74, 1937-1946 (2017).

37. Jansen, S. \& Bathmann, U. Algae viability within copepod faecal pellets: evidence from microscopic examinations. Mar. Ecol. Prog. Ser. 337, 145-153 (2007).

38. Wekerle, C. et al. Properties of sediment trap catchment areas in fram strait: results from lagrangian modeling and remote sensing. Front. Mar. Sci. 5, 1-16 (2018).

39. Schoemann, V., Becquevort, S., Stefels, J., Rousseau, V. \& Lancelot, C. Phaeocystis blooms in the global ocean and their controlling mechanisms: a review. J. Sea Res. 53, 43-66 (2005).

40. Dybwad, C. et al. Carbon export in the seasonal sea ice zone north of Svalbard from winter to late summer. Front. Mar. Sci. https://doi.org/10.3389/ fmars.2020.525800 (2021).

41. Gradinger, R. R. \& Baumann, M. E. M. Distribution of phytoplankton communities in relation to the large-scale hydrographical regime in the Fram Strait. Mar. Biol. 111, 311-321 (1991).

42. Nöthig, E.-M. et al. Summertime plankton ecology in Fram Strait-a compilation of long-and short-term observations. Polar Res. 34, (2015).

43. Assmy, P. et al. Leads in Arctic pack ice enable early phytoplankton blooms below snow-covered sea ice. Sci. Rep. 7, (2017).

44. Basedow, S. et al. Seasonal variation in transport of zooplankton into the Arctic Ocean through the Atlantic gateway. Front. Mar. Sci. 5, 1-22 (2018)

45. Hansen, B., Tande, K. S. \& Berggreen, U. C. On the trophic fate of Phaeocystis pouchetii (Harlot). III. Functional responses in grazing demonstrated on juvenile stages of Calanus finmarchicus (Copepoda) fed diatoms and Phaeocystis. J. Plankton Res. 12, 1173-1187 (1990).

46. Gooday, A. J. et al. Responses by benthic organisms to inputs of organic material to the ocean floor: a review. Philos. Trans. R. Soc. Lond. A 331 119-138 (1990).

47. Fernández-Méndez, M. et al. Composition, buoyancy regulation and fate of ice algal aggregates in the Central Arctic Ocean. PLoS ONE 9, e107452 (2014).

48. Li, Y. et al. Bay of Bengal salinity stratification and Indian summer monsoon intraseasonal oscillation: 1. Intraseasonal variability and causes. J. Geophys. Res. 122, 4291-4311 (2017).

49. Shroyer, E. L. et al. Modification of upper-ocean temperature structure by subsurface mixing in the presence of strong salinity stratification. Oceanography 29, 62-71 (2016).

50. Waite, A. M. et al. Formation and maintenance of high-nitrate, low pH layers in the eastern Indian Ocean and the role of nitrogen fixation. Biogeosciences 10, 5691-5702 (2013).

51. Kindler, K., Khalili, A. \& Stocker, R. Diffusion-limited retention of porous particles at density interfaces. Proc. Natl Acad. Sci. U.S.A. 107, 22163-22168 (2010).

52. Mignot, A., Ferrari, R. \& Claustre, H. Floats with bio-optical sensors reveal what processes trigger the North Atlantic bloom. Nat. Commun. 9, (2018)

53. Fadeev, E. et al. Sea ice presence is linked to higher carbon export and vertical microbial connectivity in the Eurasian Arctic Ocean. Commun. Biol. 4, 1255 (2021)

54. Wassmann, P. Retention versus export food chains: processes controlling sinking loss from marine pelagic systems. Hydrobiologia 363, $29-57$ (1998).

55. Olli, K. et al. Food web functions and interactions during spring and summer in the Arctic water inflow region: investigated through inverse modelling. Front. Mar. Sci. 6, 244 (2019).

56. Svensen, C. et al. Zooplankton communities associated with new and regenerated primary production in the Atlantic inflow north of Svalbard. Front. Mar. Sci. 6, 293 (2019).

57. Polyakov, I. V. et al. Greater role for Atlantic inflows on sea-ice loss in the Eurasian Basin of the Arctic. Ocean. Sci. 356, 285-291 (2017).

58. Belter, H. J. et al. Interannual variability in transpolar drift ice thickness and potential impact of atlantification. Cryosphere https://doi.org/10.5194/tc-2020305 (2020).

59. Mauritzen, C. Production of dense overflow waters feeding the north Atlantic across the Greenland-Scotland ridge. part 1: evidence for a revised circulation scheme. Deep Sea Res. Part I 43, 769-806 (1996).

60. Bauerfeind, E., Garrity, C., Krumbholz, M., Ramseier, R. O. \& Vo $\beta$, M. Seasonal variability of sediment trap collections in the Northeast Water Polynya. Part 2. Biochemical and microscopic composition of sedimenting matter. J. Mar. Syst. 10, 371-389 (1997).

61. McMahon, K. W. et al. Benthic community response to ice algae and phytoplankton in Ny Ålesund, Svalbard. Mar. Ecol. Prog. Ser. 310, 1-14 (2006)

62. Soltwedel, T. et al. Natural variability or anthropogenically-induced variation? Insights from 15 years of multidisciplinary observations at the arctic marine LTER site HAUSGARTEN. Ecol. Indic. 65, 89-102 (2016)

63. Ardyna, M. \& Arrigo, K. R. Phytoplankton dynamics in a changing Arctic Ocean. Nat. Clim. Chang 10, 892-903 (2020).

64. Jakobsson, M. et al. The international bathymetric chart of the Arctic Ocean (IBCAO) version 3.0. Geophys. Res. Lett. 39, (2012).

65. Spreen, G., Kaleschke, L. \& Heygster, G. Sea ice remote sensing using AMSR-E 89-GHz channels. J. Geophys. Res. C 113, (2008).

66. Melsheimer, C. \& Spreen, G. AMSR2 ASI sea ice concentration data, Arctic, version 5.4 (NetCDF) (July 2012 - December 2019). https://doi.org/10.1594/ PANGAEA.898399 (2019)

67. Girard-Ardhuin, F. \& Ezraty, R. Enhanced Arctic Sea ice drift estimation merging radiometer and scatterometer data. IEEE Trans. Geosci. Remote Sens. 50, 2639-2648 (2012).

68. Krumpen, T. et al. Recent summer sea ice thickness surveys in Fram Strait and associated ice volume fluxes. Cryosphere 10, 523-534 (2016).

69. Lavergne, T. Validation and Monitoring of the OSI SAF Low Resolution Sea Ice Drift Product (v5). http://osisaf.met.no/docs/osisaf_cdop2_ss2_valrep_seaice-drift-lr_v4p0.pdf (2016).

70. Dee, D. P. et al. The ERA-Interim reanalysis: configuration and performance of the data assimilation system.Quart. J. Roy. Meteor Soc. 137, 553-597 (2011).

71. Wang, Q. et al. The Finite Element Sea Ice-Ocean Model (FESOM) v. 1.4 formulation of an ocean general circulation model. Geoscientific model. Development 7, 663-693 (2014).

72. von Appen, W.-J., Schauer, U., Hattermann, T. \& Beszczynska-Möller, A. Seasonal cycle of mesoscale instability of the West Spitsbergen current. J. Phys. Oceanogr. 46, 1231-1254 (2016)

73. Zhao, M. et al. Characterizing the eddy field in the Arctic Ocean halocline. $J$. Geophys. Res. C 119, 8800-8817 (2015). 
74. Schaffer, J. et al. A global, high-resolution data set of ice sheet topography, cavity geometry, and ocean bathymetry.Earth Syst. Sci. Data 8, 543-557 (2016).

75. Wekerle, C. et al. Eddy-resolving simulation of the Atlantic water circulation in the Fram strait with focus on the seasonal cycle. J. Geophys. Res. 122, 8385-8405 (2017).

76. Tsujino, H. et al. JRA-55 based surface dataset for driving ocean-sea-ice models (JRA55-do). Ocean Model 130, 79-139 (2018).

77. Bamber, J. L. et al. Land ice freshwater budget of the Arctic and North Atlantic Oceans: 1. data, methods, and results. J. Geophys. Res. C 123, 1827-1837 (2018).

78. Price, J. F., Weller, R. A. \& Pinkel, R. Diurnal cycling: observations and models of the upper ocean response to diurnal heating, cooling, and wind mixing. $J$. Geophys. Res. 91, 8411-8427 (1986).

79. Driemel, A. et al. From pole to pole: 33 years of physical oceanography on board of R/V POLARSTERN. Earth Syst. Sci. Data 9, 211-220 (2017).

80. von Appen, W.-J. Physical oceanography and current meter data (including raw data) from FRAM moorings in the Fram Strait, 2016-2018. https:// doi.org/10.1594/PANGAEA.904565 (2019).

81. Roesler, C. et al. Recommendations for obtaining unbiased chlorophyll estimates from in situ chlorophyll fluorometers: a global analysis of WET Labs ECO sensors. Limnol. Oceanogr. Methods 15, 572-585 (2017)

82. Johnson, K. S. et al. Biogeochemical sensor performance in the SOCCOM profiling float array. J. Geophys. Res. C 122, 6416-6436 (2017).

83. von Appen, W.-J. Report on Mooring Processing of PS99.2/PS100/PS101 recoveries. https://epic.awi.de/id/eprint/43137/ (2017).

84. Mavi, H. S. \& Tupper, G. J. Agrometeorology: Principles and Applications of Climate Studies in Agriculture (CRC Press, 2004).

85. Morel, A. et al. Optical properties of the "clearest" natural waters. Limnol. Oceanogr. 52, 217-229 (2007).

86. Sakamoto, C. M., Johnson, K. S. \& Coletti, L. J. Improved algorithm for the computation of nitrate concentrations in seawater using an in situ ultraviolet spectrophotometer. Limnol. Oceanogr. Methods 7, 132-143 (2009).

87. Lewis, E. \& Wallace, D. Program Developed for $\mathrm{CO} 2$ System Calculations. Carbon Dioxide Information Analysis Center https://doi.org/10.3334/cdiac/ otg.co2sys_dos_cdiac105 (2011).

88. MacGilchrist, G. A. et al. The Arctic Ocean carbon sink. Deep Sea Res. Part I 86, 39-55 (2014).

89. Wietz, M. et al. The polar night shift: seasonal dynamics and drivers of Arctic Ocean microbiomes revealed by autonomous sampling. ISME Commun. accepted, (2021).

90. Metfies, K. et al. Protist communities in moored long-term sediment traps (Fram Strait, Arctic)-Preservation with Mercury Chloride allows for PCRbased molecular genetic analyses. Front. Mar. Sci. 4, 301 (2017).

91. Parada, A. E., Needham, D. M. \& Fuhrman, J. A. Every base matters: assessing small subunit rRNA primers for marine microbiomes with mock communities, time series and global field samples. Environ. Microbiol. 18, 1403-1414 (2016).

92. Fadeev, E. et al. Microbial communities in the east and west fram strait during sea ice melting season. Front. Mar. Sci. 5, 429 (2018)

93. Martin, M. Cutadapt removes adapter sequences from high-throughput sequencing reads. EMBnet. J. 17, 10-12 (2011).

94. Callahan, B. J. et al. DADA2: High-resolution sample inference from Illumina amplicon data. Nat. Methods 13, 581-583 (2016).

95. Deines, K. L. Backscatter estimation using broadband acoustic Doppler current profilers. In Proceedings of the IEEE Sixth Working Conference on Current Measurement (Cat. No. 99CH36331) 249-253 (IEEE, 1999).

96. Cisewski, B., Strass, V. H., Rhein, M. \& Krägefsky, S. Seasonal variation of diel vertical migration of zooplankton from ADCP backscatter time series data in the Lazarev Sea. Antarctica. Deep Sea Res. Part I 57, 78-94 (2010).

97. Wenzhöfer, F., Lemburg, J., Hofbauer, M., Lehmenhecker, S. \& Faerber, P. TRAMPER: An autonomous crawler for long term benthic oxygen flux studies in remote deep sea ecosystems. in OCEANS 2016 MTS/IEEE Monterey 1-6 (2016).

98. Melsheimer, C., Spreen, G. AMSR2 ASI sea ice concentration data, Arctic, version 5.4 (NetCDF) (July 2012 - December 2019). PANGAEA, https:// doi.org/10.1594/PANGAEA.898399 (2019).

99. von Appen, W.-J., Rohardt, G. Physical oceanography during POLARSTERN cruise PS107 (ARK-XXXI/2). PANGAEA, https://doi.org/10.1594/PANGAEA.89 4189 (2018)

100. von Appen, W.-J. Underway CTD raw data collected during POLARSTERN cruise PS107. PANGAEA, https://doi.org/10.1594/PANGAEA.886146 (2018).

101. von Appen, W.-J., Schaffer, J., Rohardt, G., Wisotzki, A. Physical oceanography during POLARSTERN cruise PS114. PANGAEA, https:// doi.org/10.1594/PANGAEA.898694 (2019).

102. Hopkins J., Brennan D., Abell R., Sanders R. W., Mountifield D. CTD data from NERC Changing Arctic Ocean Cruise JR17005 on the RRS James Clark Ross, May-June 2018 (version 2). British Oceanographic Data Centre, https:// doi.org/10/c4g3 (2019).
103. von Appen, W.-J. Physical oceanography and current meter data (including raw data) from FRAM moorings in the Fram Strait, 2016-2018. PANGAEA, https://doi.org/10.1594/PANGAEA.904565 (2019).

104. Torres-Valdés, S., et al. FRAM remote access samplers: nutrient and associated sensor data. PANGAEA, https://doi.org/10.1594/PANGAEA.936749 (2021)

105. Min, C. et al. Sea ice export through the Fram Strait derived from a combined model and satellite data set. Cryosphere 13, 3209-3224 (2019).

\section{Acknowledgements}

We thank the FRAM associated technicians, engineers, and administrators as well as the captains, crews, and chief scientists of the cruises who were all instrumental in making these observations possible. We thank T. Kanzow, M. Janout, J. Schaffer, M. Nielsdóttir, and E. Bonk for helpful discussions and contributions to the observational implementation. We thank P. Matrai and an anonymous reviewer for their appreciative reviews. Ship time was provided under grants AWI_PS99_00, AWI_PS100_01, AWI_PS107_05, AWI_PS108_00, AWI_PS114_01, AWI_PS121_01 of RV Polarstern and data was also obtained on cruises MSM76 and MSM77 of RV Maria S. Merian. The work was supported by the North-German Supercomputing Alliance (HLRN). We thank NOAA/NCEI and the World Data Service for Geophysics for providing the IBCAO bathymetry, the University of Bremen for providing the AMSR2 sea ice concentration, ESA for providing the Sentinel 3 A OLCI chlorophyll concentration, and ECMWF for providing the ERA-I reanalysis. We acknowledge support by the Open Access Publication Funds of Alfred-Wegener-Institut Helmholtz Zentrum für Polarund Meeresforschung.

\section{Author contributions}

Conceptualization: W.J.v.A., I.S. and A.B. Methodology: W.J.v.A., M.B., C.B., O.B., A.Br., M.H.I., C.K., T.K., N.L., K.M., B.N., E.M.N., A.P., I.S., D.S., T.S., S.T.V., C.W., F.W. and A.B. Formal analysis: W.J.v.A., M.B., C.B., A.Br., B.C., M.H., M.H.I., T.K., K.M., B.N., E.M.N., A.P., I.S., M.S., S.T.V., C.W., F.W. and M.W. Investigation: W.J.v.A., M.B., C.B., J.H., M.H.I., C.K., T.K., N.L., K.M., A.P., I.S., D.S., T.S., S.T.V., F.W. and M.W. Data Curation: W.J.v.A. Writing - Original Draft: W.J.v.A. and A.M.W. Writing-Review \& Editing: W.J.v.A., A.M.W., M.B., C.B., O.B., A.Br., B.C., M.H., M.H.I., T.K., K.M., B.N., E.M.N., A.P., I.S., M.S., D.S., T.S., S.T.V., C.W., F.W., M.W. and A.B. Visualization: W.J.v.A., T.K. and C.W. Funding acquisition: T.S. and A.B.

\section{Funding}

Helmholtz Infrastructure Initiative FRAM ("Frontiers in Arctic Marine Monitoring") (A.B.). Ocean Frontier Institute and the Canada First Research Excellence Fund (W.J.v.A., A.M.W.). Open Access funding enabled and organized by Projekt DEAL.

\section{Competing interests}

The authors declare no competing interests.

\section{Additional information}

Supplementary information The online version contains supplementary material available at https://doi.org/10.1038/s41467-021-26943-z.

Correspondence and requests for materials should be addressed to Wilken-Jon von Appen.

Peer review information Nature Communications thanks Patricia Matrai and the other, anonymous, reviewer(s) for their contribution to the peer review of this work. Peer reviewer reports are available.

Reprints and permission information is available at http://www.nature.com/reprints

Publisher's note Springer Nature remains neutral with regard to jurisdictional claims in published maps and institutional affiliations.

\footnotetext{
Open Access This article is licensed under a Creative Commons Attribution 4.0 International License, which permits use, sharing, adaptation, distribution and reproduction in any medium or format, as long as you give appropriate credit to the original author(s) and the source, provide a link to the Creative Commons license, and indicate if changes were made. The images or other third party material in this article are included in the article's Creative Commons license, unless indicated otherwise in a credit line to the material. If material is not included in the article's Creative Commons license and your intended use is not permitted by statutory regulation or exceeds the permitted use, you will need to obtain permission directly from the copyright holder. To view a copy of this license, visit http://creativecommons.org/ licenses/by/4.0/.
}

(C) The Author(s) 2021 